Article

\title{
Electron Donor Utilization and Secondary Mineral Formation during the Bioreduction of Lepidocrocite by Shewanella putrefaciens CN32
}

\author{
Edward J. O'Loughlin ${ }^{1, *}$, Christopher A. Gorski ${ }^{2,3}{ }^{(0}$, Theodore M. Flynn ${ }^{1,4}{ }^{(1)}$ and \\ Michelle M. Scherer ${ }^{2}$ \\ 1 Biosciences Division, Argonne National Laboratory, Lemont, IL 60439-4843, USA \\ 2 Department of Civil and Environmental Engineering, University of Iowa, Iowa City, IA 52242-1527, USA \\ 3 Department of Civil and Environmental Engineering, The Pennsylvania State University, University Park, \\ PA 16802-7304, USA \\ 4 California Department of Water Resources, 3500 Industrial Blvd, West Sacramento, CA 96691, USA \\ * Correspondence: oloughlin@anl.gov; Tel.: +1-630-252-9902
}

Received: 30 April 2019; Accepted: 4 July 2019; Published: 14 July 2019

check for updates

\begin{abstract}
The bioreduction of Fe(III) oxides by dissimilatory iron reducing bacteria (DIRB) may result in the production of a suite of Fe(II)-bearing secondary minerals, including magnetite, siderite, vivianite, green rusts, and chukanovite; the formation of specific phases controlled by the interaction of various physiological and geochemical factors. In an effort to better understand the effects of individual electron donors on the formation of specific Fe(II)-bearing secondary minerals, we examined the effects of a series of potential electron donors on the bioreduction of lepidocrocite ( $\gamma$-FeOOH) by Shewanella putrefaciens CN32. Biomineralization products were identified by X-ray diffraction, Mössbauer spectroscopy, and scanning electron microscopy. Acetate, citrate, ethanol, glucose, glutamate, glycerol, malate, and succinate were not effectively utilized for the bioreduction of lepidocrocite by S. putrefaciens CN32; however, substantial Fe(II) production was observed when formate, lactate, $\mathrm{H}_{2}$, pyruvate, serine, or N acetylglucosamine (NAG) was provided as an electron donor. Carbonate or sulfate green rust was the dominant $\mathrm{Fe}(\mathrm{II})$-bearing secondary mineral when formate, $\mathrm{H}_{2}$, lactate, or NAG was provided, however, siderite formed with pyruvate or serine. Geochemical modeling indicated that $\mathrm{pH}$ and carbonate concentration are the key factors determining the prevalence of carbonate green rust verses siderite.
\end{abstract}

Keywords: green rust; siderite; dissimilatory iron reduction; iron oxide

\section{Introduction}

Iron (Fe) is a highly abundant element in the lithosphere. Fe-bearing clay minerals (smectites, illites, chlorites, etc.) and Fe oxides (including formal Fe oxides, oxyhydroxides, and hydroxides such as ferrihydrite, hematite $\left(\alpha-\mathrm{Fe}_{2} \mathrm{O}_{3}\right)$, maghemite $\left(\gamma-\mathrm{Fe}_{2} \mathrm{O}_{3}\right)$, magnetite $\left(\mathrm{Fe}_{3} \mathrm{O}_{4}\right)$, goethite $(\alpha-\mathrm{FeOOH})$, and lepidocrocite $(\gamma-\mathrm{FeOOH}))$ are common constituents of soils and sediments. The biogeochemistry of Fe in most aquatic and terrestrial environments is driven largely by microbial activity, particularly in Fe-rich soils and sediments where Fe redox cycling by microorganisms is a significant component of C cycling and energy flux [1-5]. As such, the presence of Fe(II) in suboxic to anoxic near surface environments is typically the result of the activity of dissimilatory iron-reducing (DIR) bacteria and archaea. These phylogenetically diverse microorganisms can couple the oxidation of organic compounds or hydrogen $\left(\mathrm{H}_{2}\right)$ to the reduction of $\mathrm{Fe}(\mathrm{III})$ to $\mathrm{Fe}(\mathrm{II})$ [6-19]. As a group, dissimilatory iron-reducing bacteria (DIRB) are able to use soluble Fe(III) complexes (e.g., ferric citrate), Fe(III) oxides, and Fe(III)-bearing clay minerals as terminal electron acceptors for anaerobic respiration [20-28]. 
Living biomass aside, the pool of natural organic matter (NOM) in typical surface and near-subsurface environments is comprised primarily of low-molecular-mass components $(<1 \mathrm{kDa})$ that usually include fatty acids and free sugars and amino acids, along with high-molecular-mass $(>1 \mathrm{kDa})$ components that consist largely of humic substances, with lesser amounts of proteins, carbohydrates, and other non-humic macromolecules [29]. The pool of NOM is highly dynamic, largely due to microbial activity. Under anoxic conditions, complex NOM (e.g., proteins, carbohydrates, and lipids) are depolymerized by hydrolytic enzymes from a broad range of microorganisms [30] and the hydrolysis products (e.g., amino acids, monosaccharide, and fatty acids), serve as substrates for fermentation. In turn, fermentative microorganisms produce a suite of fatty acids (formate, acetate, lactate), alcohols (ethanol, butanol), and $\mathrm{H}_{2}$, which can be utilized as electron donors for anaerobic respiration by a broad range of facultative and obligate anaerobes including DIRB [31].

The products of DIR comprise a broad range of Fe(II) species including soluble and adsorbed $\mathrm{Fe}(\mathrm{II})$ and mineral phases containing structural $\mathrm{Fe}(\mathrm{II})$ (e.g., magnetite, siderite $\left(\mathrm{FeCO}_{3}\right)$, vivianite $\left[\mathrm{Fe}_{3}\left(\mathrm{PO}_{4}\right)_{2} \cdot 8 \mathrm{H}_{2} \mathrm{O}\right]$, green rust, chukanovite $\left[\mathrm{Fe}_{2}(\mathrm{OH})_{2} \mathrm{CO}_{3}\right]$, and $\mathrm{Fe}(\mathrm{II})$-bearing clays) [32-40]. Many factors have been identified as contributing to the formation of specific $\mathrm{Fe}$ (II)-bearing secondary minerals as products of DIR, including Fe(III) oxide mineralogy, [20,35]; Fe(III) oxide particle aggregation, [41]; the rate and extent of $\mathrm{Fe}(\mathrm{II})$ production, [33,35,42,43]; the presence of electron shuttles, [33]; the species and population size of the DIRB, [44-46]; the presence of oxyanions (phosphate, silicate, molybdate, arsenate, etc.), [33,44,47-49]; the type/nature of dissolved NOM (including humic substances and microbially produced extracellular polymeric materials) $[44,46,50]$; and the concentration and type of electron donor [51-53]. Many of these parameters are interdependent (e.g., the rate of Fe(III) reduction may be controlled by the metabolic constraints placed on a given DIRB by the type and amount of electron donor available or by the system $\mathrm{pH}$ ), often making it difficult to determine their relative contributions to the formation of specific Fe(II)-bearing secondary minerals.

The taxonomic diversity of DIRB is reflected in the broad range of electron donors that support DIR [54]; however, the effects of specific electron donors on the distribution of biogenic Fe(II) phases produced during DIR have not been extensively studied. The bioreduction of akaganeite $(\beta-\mathrm{FeOOH})$ by Shewanella sp. HN-41 resulted in the formation of magnetite, siderite, and a combination of magnetite and siderite when lactate, pyruvate, and formate, respectively, were provided as electron donors [52]. Salas et al. [53] reported formation of siderite, green rust, and a combination of green rust and magnetite during DIR of ferrihydrite by Shewanella putrefaciens W3-18-1 with pyruvate, uridine, and lactate, respectively, as electron donors. Both of these studies show a pronounced effect of specific electron donors on the formation of specific secondary minerals. However, in each case only three donors were investigated, thus additional studies examining a broader range of electron donors are needed to develop a more comprehensive understanding of the key factors that determine the distribution of $\mathrm{Fe}(\mathrm{II})$-bearing secondary minerals resulting from DIR of Fe(III) oxides.

In this study we examine the ability of Shewanella putrefaciens CN32 to utilize a broad range of potential electron donors for anaerobic respiration using Fe(III) oxide as an electron acceptor for anaerobic respiration. Formation of Fe(II)-bearing secondary minerals was determined using X-ray diffraction (XRD), ${ }^{57} \mathrm{Fe}$ Mössbauer spectroscopy, and scanning electron microscopy (SEM).

\section{Materials and Methods}

\subsection{Experimental Setup}

The organic electron donor survey experiment was conducted in sterile $160-\mathrm{mL}$ serum bottles containing $100 \mathrm{~mL}$ of sterile defined mineral medium (DMM) [55] with Fe(III) as lepidocrocite $(80 \mathrm{mM}$; Bayferrox 943, LANXESS Corp., Leverkusen, Germany/Pittsburgh, PA, USA), electron donor (75 mM acetate, L-alanine, citrate, ethanol, formate, D-glucose, L-glutamate, glycerol, glycine, DL-lactate, malate, N-acetyl glucosamine (NAG), propionate, pyruvate, L-serine, or succinate), and $100 \mu \mathrm{M}$ 9,10-anthraquinone 2,6 disulfonate (AQDS). Characterization of the lepidocrocite used in this study is 
provided in O'Loughlin et al. [28] The DMM was prepared by combining all components (except the electron donor and AQDS), the $\mathrm{pH}$ was adjusted to 7.5 by titration with $1 \mathrm{M} \mathrm{NaOH}$, portioned into serum bottles, and autoclaved. After the medium cooled to ambient temperature, the electron donor and AQDS were added from filter-sterilized stock solutions. The bottles were sealed with rubber septa and aluminum crimp caps and made anoxic by sparging with sterile argon. Additional experiments with select organic electron donors (i.e., donors that supported DIR in the survey experiment) were conducted in $250-\mathrm{mL}$ serum bottles containing $200 \mathrm{~mL}$ of DDM prepared in the same manner as described above and amended with either $25 \mathrm{mM} \mathrm{NaCl}$ or $25 \mathrm{mM} \mathrm{Na}_{2} \mathrm{SO}_{4}$. Bottles in which $\mathrm{H}_{2}$ was provided as the electron donor were prepared in a similar manner but with $50 \mathrm{~mL}$ of DMM (amended with $25 \mathrm{mM}$ of either $\mathrm{NaCl}, \mathrm{NaHCO}_{3}$, or $\mathrm{Na}_{2} \mathrm{SO}_{4}$ ) in 500 -mL serum bottles and the headspace was flushed with sterile $\mathrm{H}_{2}$ after sparging with argon (resulting in $>20 \mathrm{mmol} \mathrm{H}_{2}$ ). An additional set of bottles with $\mathrm{H}_{2}$ as the electron donor was prepared containing $0.5 \mathrm{~g}$ of sterile Pd catalyst $(0.5 \mathrm{wt} \% \mathrm{Pd}$ on 3.2-mm alumina pellets) and $25 \mathrm{mM} \mathrm{NaHCO}_{3}$. All experimental systems were prepared in triplicate.

The inoculum was prepared from late-log-phase cultures of S. putrefaciens CN32 (American Type Culture Collection BAA-543) as described by O'Loughlin et al. [16]. Experiments were initiated by spiking each bottle with the volume of inoculum needed to achieve a cell density of $5 \times 10^{9}$ cells $^{\mathrm{mL}^{-1}}$. The bottles were placed on a roller drum and incubated at $30{ }^{\circ} \mathrm{C}$ in the dark. Samples of the suspensions-for monitoring $\mathrm{pH}, \mathrm{Fe}$ (II) production, and consumption of electron donors as well as for identification of secondary minerals by X-ray diffraction (XRD), scanning electron microscopy (SEM), and ${ }^{57} \mathrm{Fe}$ Mössbauer spectroscopy-were collected with sterile syringes. Unless otherwise indicated, sample collection and processing were conducted in a glove box containing an anoxic atmosphere $\left(95 \% \mathrm{~N}_{2}\right.$ with $\left.5 \% \mathrm{H}_{2}\right)$.

\subsection{Analytical Methods}

The reduction of Fe(III) was monitored by measuring the total Fe(II) content of $0.75 \mathrm{M} \mathrm{HCl}$ extracts of the suspensions $\left(\mathrm{Fe}(\mathrm{II})_{\mathrm{tot}}\right.$, referred to hereafter as $\mathrm{Fe}(\mathrm{II})$ ). Samples for $\mathrm{Fe}(\mathrm{II})$ analysis were prepared by adding $0.75 \mathrm{~mL}$ of anoxic $1 \mathrm{M} \mathrm{HCl}$ to $0.25 \mathrm{~mL}$ of suspension. After 1 week, the samples were centrifuged at $25,000 \times g$ for $10 \mathrm{~min}$. The $\mathrm{Fe}(\mathrm{II})$ concentrations in the supernatants were determined by the ferrozine assay [56]. Briefly, $1 \mathrm{~mL}$ of HEPES-buffered ferrozine reagent [57] was added to $50 \mu \mathrm{L}$ of supernatant, and the absorbance at $562 \mathrm{~nm}$ was measured.

The disappearance of lepidocrocite and the formation of secondary minerals were monitored by powder X-ray diffraction (pXRD) with a Rigaku MiniFlex X-ray diffractometer (Rigaku Corporation, Tokyo, Japan) with Ni-filtered $\mathrm{Cu} K \alpha$ radiation. Samples for $\mathrm{pXRD}$ analysis were collected by filtration on 25-mm, $0.22-\mu \mathrm{m}$ nylon filters and covered with 8.4-mm-thick Kapton ${ }^{\circledR}$ film under anoxic conditions; although the pXRD analysis was conducted under ambient atmosphere, samples prepared in this manner showed no evidence of oxidation when scanned between $5^{\circ}$ and $80^{\circ} 2 \theta$ at a speed of $1.25^{\circ} 2 \theta$ $\mathrm{min}^{-1}$. The pXRD patterns were analyzed with the JADE 7 software package (MDI, Livermore, CA, USA) to remove the background through polynomial fitting and also to remove the $\mathrm{K} \alpha_{2}$ components. Samples of the filtrate were saved for $\mathrm{pH}$ measurement, measurement of dissolved $\mathrm{Fe}(\mathrm{II})$ [Fe(II) $)_{\mathrm{aq}}$ )] using the ferrozine assay, and for analysis of organic electron donors using an Agilent 1100 series HPLC equipped with a UV-Vis absorbance detector (Agilent Technologies, Inc., Santa Clara, CA, USA). The samples for HPLC analysis were diluted with an equal volume of $10 \mathrm{mM} \mathrm{H}_{2} \mathrm{SO}_{4}$, and $50 \mu \mathrm{L}$ of the diluted sample was injected on a Bio-Rad Aminex HPX-87H ion-exchange column $(7.8 \times 300 \mathrm{~mm}$, Bio-Rad Laboratories Inc., Hercules, CA, USA). The column was eluted isocratically with $5 \mathrm{mM} \mathrm{H}_{2} \mathrm{SO}_{4}$ at a flow rate of $0.6 \mathrm{~mL} \mathrm{~min}^{-1}$ at $50{ }^{\circ} \mathrm{C}$ with analyte detection at $210 \mathrm{~nm}$. The $\mathrm{pH}$ was measured with a precision of 0.01 using a Semi Micro $\mathrm{pH}$ electrode (Thermo Fisher Scientific Inc., Waltham, MA, USA) calibrated with NIST-traceable $\mathrm{pH}$ standards.

Samples for SEM imaging were prepared by placing $500 \mu \mathrm{L}$ of suspension on aluminum specimen mounts, allowing the solids to settle, removing the overlying liquid with a pipette, and drying the film 
of solids in a glove box. Specimens were briefly $(<30 \mathrm{~s})$ exposed to air during transfer to the Hitachi S-4700-II FEG-SEM (Hitachi High-Technologies Corporation, Tokyo, Japan).

Transmission Mössbauer spectroscopy was performed with a variable temperature He-cooled system with a 1024 channel detector. The ${ }^{57}$ Co source used ( $\left.~ 50 \mathrm{mCi}\right)$ was in a Rh matrix at room temperature. All center shifts reported are relative to an $\alpha$-Fe foil at room temperature. Samples were prepared by filtering the suspension (approximately $4 \mathrm{~mL}$ ) in an anoxic glove box with recoverable filter paper. The filter paper was then sealed between two pieces of $5 \mathrm{~mm}$ Kapton tape to avoid oxidation while the sample was mounted. No indication of inadvertent oxidation was observed. Spectral fitting was done using Recoil Software version 1.01998 (University of Ottawa, Ottawa, ON, Canada). Voigt-based fitting was used to model the spectra to determine the hyperfine parameters and the relative areas between phases. The Lorentzian linewidth was held at $0.12 \mathrm{~mm} \mathrm{~s}^{-1}$, as it was the linewidth measured on the spectrometer for an ideally thick $\alpha$-Fe foil. The relative peak areas (1:1 for doublets, 3:2:1:1:2:3 for sextets) were held constant throughout fitting. Each phase was fitted with only a single component (i.e., multiple QS and $\mathrm{H}$ distributions were not allowed for a single phase in fitting).

\subsection{Thermodynamic Modeling}

Geochemical models of the Fe-C system were created using The Geochemist's Workbench software suite (version 8.0.12, Aqueous Solutions LLC, Champaign, IL, USA) [58]. The program Act2 was used to create Pourbaix (Eh-pH) diagrams showing the stability fields of the minerals that would be expected to form across a range of likely conditions for these microcosms. Thermodynamic data was obtained from the "thermo.dat" database in The Geochemist's Workbench [59] with the addition of lepidocrocite [60], carbonate green rust [61], and ferrous hydroxycarbonate [62].

Eh-pH diagrams were constrained by the activity of ferrous iron $\left(a\left[\mathrm{Fe}^{2+}\right]\right)$ and bicarbonate $\left(a\left[\mathrm{HCO}_{3}{ }^{-}\right]\right)$as calculated using the program React with the components of DMM as basis species. Ferrous and ferric minerals not observed to form in the system (hematite, magnetite, goethite, wüstite) were suppressed. The value of $a\left[\mathrm{HCO}_{3}{ }^{-}\right]$was modeled by adding it as a simple reactant at $\mathrm{pH} 7.5$, the initial starting $\mathrm{pH}$ of the system. As the concentration of $\mathrm{HCO}_{3}{ }^{-}$was not measured directly during the experiments, a range of possible $a\left[\mathrm{HCO}_{3}{ }^{-}\right]$was calculated and used to create separate Eh-pH diagrams to examine the effect of the range of $a\left[\mathrm{HCO}_{3}{ }^{-}\right]$on the stability of secondary iron minerals.

\section{Results}

\subsection{Electron Donor Survey}

The production of Fe(II) by S. putrefaciens CN32 in the presence of lepidocrocite and a broad range of potential electron donors is shown in Figure 1. In the absence of an exogenous electron donor, lepidocrocite reduction by S. putrefaciens $\mathrm{CN} 32$ was limited; within 72 days only $3.6 \mathrm{mM}$ Fe(II) was produced. Systems amended with acetate, alanine, citrate, ethanol, glucose, glutamate, glycerol, glycine, malate, propionate, or succinate showed slightly higher levels of Fe(II) production $(<7 \mathrm{mM})$. Significantly greater Fe(II) production was observed in systems amended with formate ( $58 \mathrm{mM}$ ), lactate (57 mM), $\mathrm{H}_{2},(18 \mathrm{mM})$, NAG (61 mM), pyruvate (57 mM), and serine (58 mM); DIR by S. putrefaciens $\mathrm{CN} 32$ using these electron donors was examined in greater detail in a more focused set of experiments, the results of which follow. 


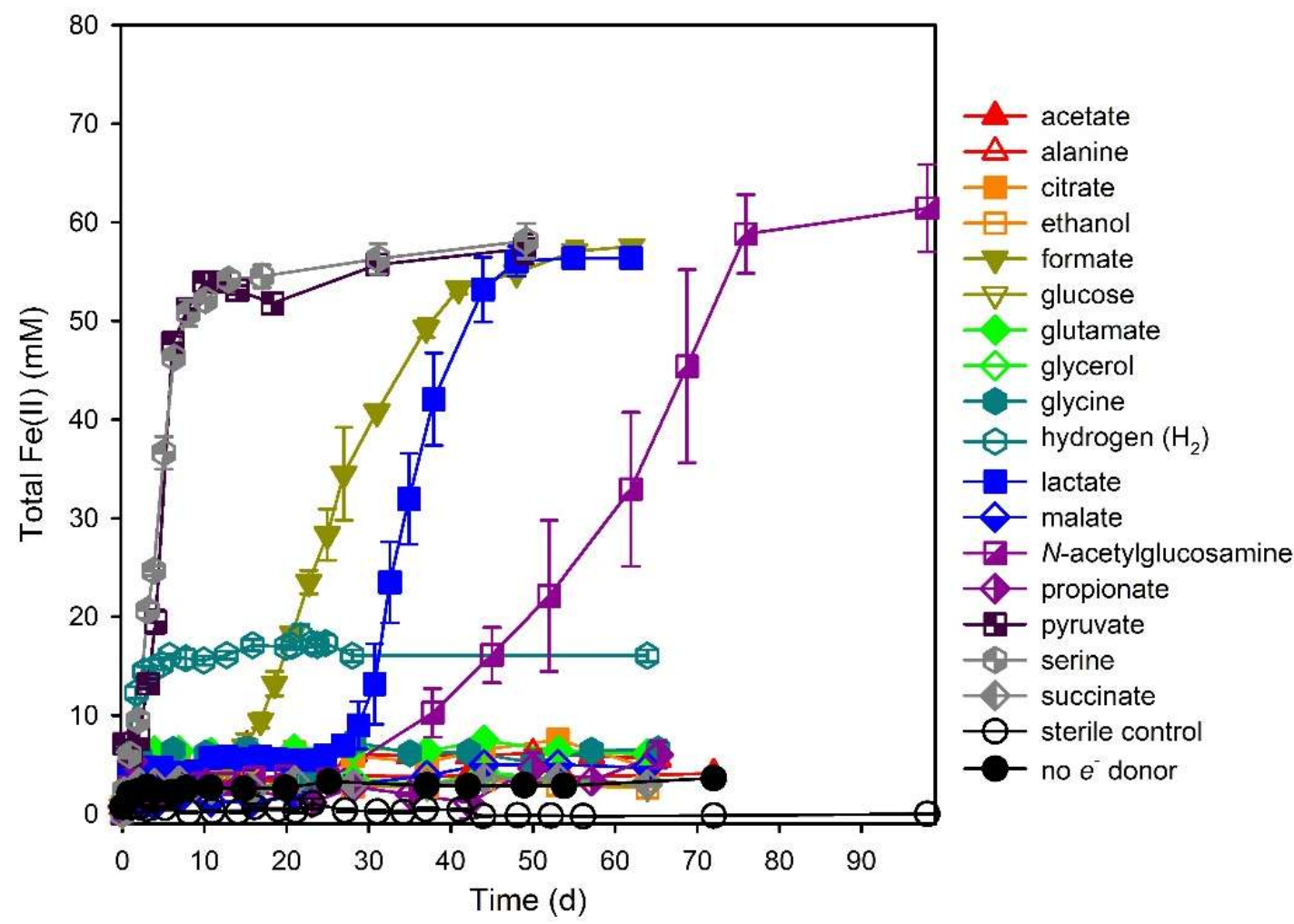

Figure 1. Fe(II) production during the bioreduction of lepidocrocite by S. putrefaciens CN32 as a function of available electron donor.

\subsection{Hydrogen}

Fe(II) production by S. putrefaciens CN32 was essentially immediate with $\mathrm{H}_{2}$ as the electron donor (Figure 2). The presence of specific anions had a significant effect on both the rate and extent of $\mathrm{Fe}(\mathrm{II})$ production, which were highest in the presence of carbonate (Table 1). Fe(II) concentrations approached steady state within 3 days and were largely unaffected by replenishment of headspace $\mathrm{H}_{2}$ or re-inoculation with freshly cultured S. putrefaciens CN32. Moreover, substantially higher levels of $\mathrm{Fe}(\mathrm{II})$ were observed in the abiotic system containing Pd catalyst as an abiotic surrogate for microbial reduction of lepidocrocite (either by direct reduction or indirect reduction involving AQDS as an electron shuttle). In all systems the $\mathrm{pH}$ increased commensurate with the extent of $\mathrm{Fe}(\mathrm{II})$ production. Green rust was the only secondary mineral identified by pXRD and Mössbauer spectroscopy (Tables 2 and 3, Figure 3). Carbonate green rust formed in the chloride- and carbonate-amended systems and sulfate green rust formed in the sulfate-amended system (Figure 3). The solids consisted primarily of platy hexagonal particles up to $5 \mu \mathrm{m}$ across, covered in tabular submicron-sized particles of unreacted lepidocrocite (Figure 4A,B). 

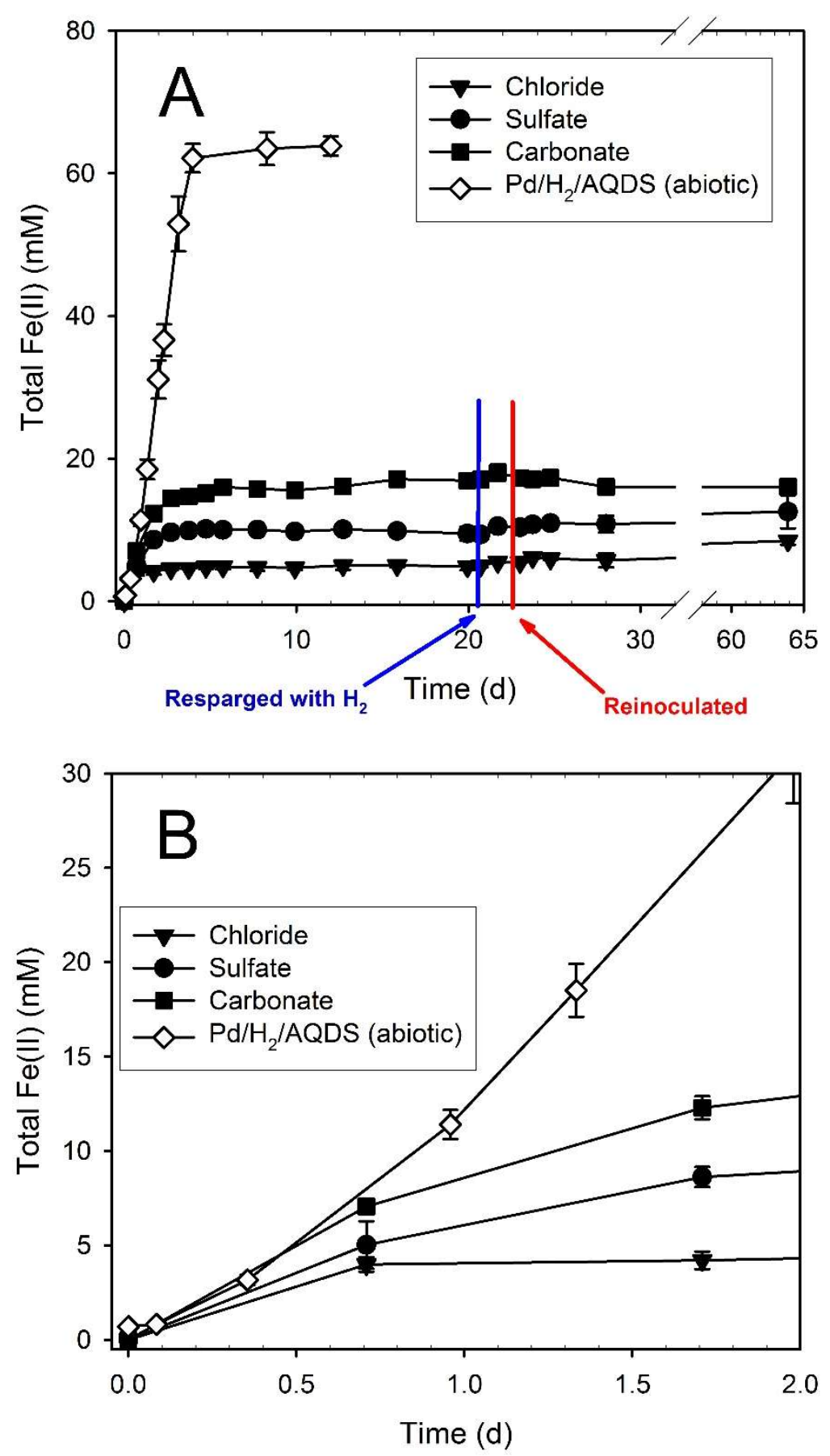

Figure 2. (A) Fe(II) production during the bioreduction of lepidocrocite by S. putrefaciens CN32 using $\mathrm{H}_{2}$ as an electron donor in the presence of either chloride, sulfate, or carbonate, compared to abiotic reduction of lepidocrocite by $\mathrm{H}_{2}$ in the presence of $\mathrm{Pd}$ catalyst, the electron shuttle 9,10-anthraquinone 2,6 disulfonate (AQDS), and carbonate and (B) an expanded view of Fe(II) production within the first 2 days. Error bars indicate one standard deviation. 


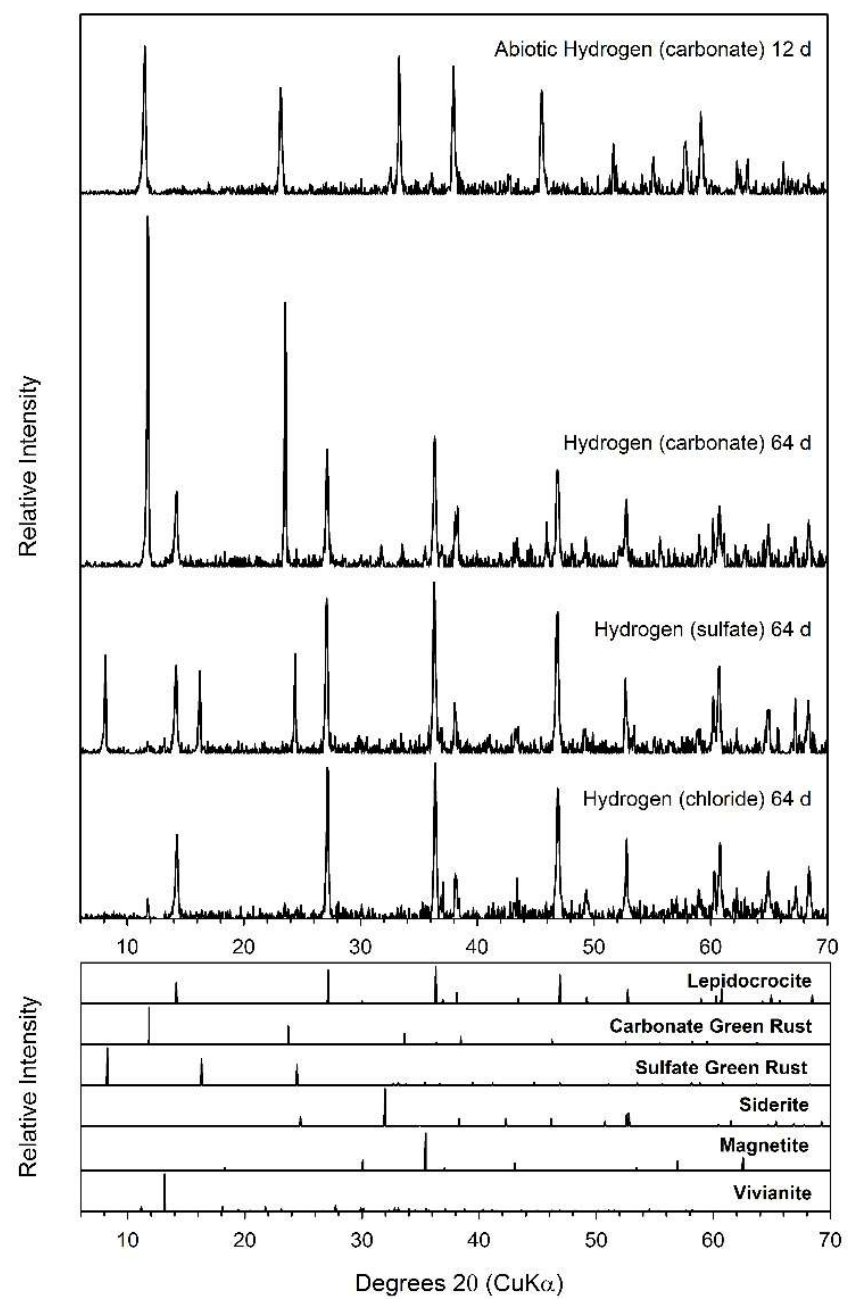

Figure 3. Powder X-ray diffraction analysis of the solids in the $\mathrm{H}_{2}$-amended systems at the end of the incubations. 
Table 1. Final $\mathrm{pH}, \mathrm{Fe}(\mathrm{II})$, and acetate concentrations, maximum Fe(II) production rates, and $e^{-}$donor consumption ratios.

\begin{tabular}{|c|c|c|c|c|c|c|}
\hline System & Final ${ }^{a} \mathrm{pH}$ & $\begin{array}{l}\text { Final Fe(II) })_{a q} \\
\quad(m M)\end{array}$ & $\begin{array}{l}\text { Final Fe(II) })_{\text {tot }} \\
(\mathrm{mM})\end{array}$ & $\begin{array}{c}\mathrm{Fe}(\mathrm{II})_{\text {tot }} \text { Production } \\
\text { during Bioreduction }{ }^{c} \\
\left(\mathrm{mmol} \mathrm{d}^{-1}\right)\end{array}$ & $\begin{array}{c}e^{-} \text {Donor Consumed } \\
(\mathrm{mM})\end{array}$ & $\begin{array}{c}\mathrm{Fe}(\mathrm{II})_{\text {tot }}: e^{-} \text {Donor } \\
\text { Consumed }\end{array}$ \\
\hline Formate (chloride) & $9.05 \pm 0.01$ & $0.8 \pm 0.1$ & $57.6 \pm 0.2$ & $2.32 \pm 0.09$ & $27.7 \pm 1.4$ & 2.1 \\
\hline Formate (sulfate) & $9.06 \pm 0.05$ & $0.7 \pm 0.1$ & $55.1 \pm 2.4$ & $1.39 \pm 0.09$ & $25.3 \pm 1.9$ & 2.2 \\
\hline $\mathrm{H}_{2}$ abiotic & $9.30 \pm 0.01$ & $\mathrm{ND}^{b}$ & $63.8 \pm 1.3$ & $16.36 \pm 0.52$ & ND & ND \\
\hline $\mathrm{H}_{2}$ (carbonate) & $8.83 \pm 0.13$ & $0.8 \pm 0.1$ & $16.0 \pm 0.6$ & $7.07 \pm 1.31$ & ND & ND \\
\hline $\mathrm{H}_{2}$ (sulfate) & $8.59 \pm 0.09$ & $0.9 \pm 0.1$ & $12.6 \pm 2.3$ & $7.09 \pm 0.97$ & ND & ND \\
\hline $\mathrm{H}_{2}$ (chloride) & $8.36 \pm 0.11$ & $1.2 \pm 0.3$ & $8.5 \pm 0.6$ & $5.64 \pm 0.95$ & ND & ND \\
\hline Lactate (chloride) & $8.01 \pm 0.01$ & $4.7 \pm 0.1$ & $56.4 \pm 0.8$ & $3.76 \pm 0.23$ & $22.6 \pm 1.3$ & 2.5 \\
\hline Lactate (sulfate) & $8.23 \pm 0.03$ & $2.9 \pm 0.1$ & $59.3 \pm 4.8$ & $3.18 \pm 0.12$ & $22.6 \pm 1.4$ & 2.6 \\
\hline NAG (chloride) & $7.55 \pm 0.10$ & $6.8 \pm 2.2$ & $61.4 \pm 4.4$ & $1.31 \pm 0.14$ & $38.4 \pm 2.8$ & 1.6 \\
\hline NAG (sulfate) & $7.69 \pm 0.04$ & $6.8 \pm 0.7$ & $70.6 \pm 3.7$ & $1.57 \pm 0.24$ & $40.9 \pm 2.1$ & 1.7 \\
\hline Pyruvate (chloride) & $8.47 \pm 0.05$ & $2.0 \pm 0.1$ & $57.3 \pm 1.5$ & $9.84 \pm 1.63$ & 75 & 0.8 \\
\hline Pyruvate (sulfate) & $8.44 \pm 0.04$ & $1.8 \pm 0.2$ & $59.3 \pm 5.7$ & $10.20 \pm 1.91$ & 75 & 0.8 \\
\hline Serine (chloride) & $8.17 \pm 0.02$ & $2.3 \pm 0.1$ & $58.1 \pm 1.8$ & $7.25 \pm 0.34$ & 75 & 0.8 \\
\hline Serine (sulfate) & $8.46 \pm 0.29$ & $1.4 \pm 1.0$ & $61.0 \pm 7.0$ & $8.38 \pm 0.28$ & 75 & 0.8 \\
\hline
\end{tabular}

${ }^{a}$ Final measurements were made at 49 days after inoculation in the pyruvate and serine systems, at 62 days in the formate and lactate systems, 64 days in the hydrogen systems, and at 106 days in the NAG systems; ${ }^{b}$ Not determined (ND); ${ }^{c} \mathrm{Fe}(\mathrm{II})$ production rates were calculated by linear regression using least-squares regression of the data during the period of maximum sustained $\mathrm{Fe}(\mathrm{II})$ production. 
Table 2. Fit parameters from Mössbauer analysis of the secondary minerals.

\begin{tabular}{|c|c|c|c|c|c|c|}
\hline Sample & $\begin{array}{c}\text { Temp } \\
\text { (K) }\end{array}$ & $\begin{array}{c}\mathrm{CS} \\
\left(\mathrm{mm} \mathrm{s}^{-1}\right)\end{array}$ & $\begin{array}{c}\text { QS } \\
\left(\mathrm{mm} \mathrm{s}^{-1}\right)\end{array}$ & $\begin{array}{c}\mathbf{H} \\
(\mathrm{T})\end{array}$ & Mineral & $\begin{array}{l}\text { RA } \\
(\%)\end{array}$ \\
\hline \multirow[t]{4}{*}{ Formate (chloride) } & 77 & 1.26 & 2.83 & - & Green Rust Fe(II) & 70.5 \\
\hline & - & 0.48 & 0.38 & - & Green Rust Fe(III) & 29.5 \\
\hline & 13 & 1.27 & 2.80 & - & Green Rust Fe(II) & 69.9 \\
\hline & - & 0.49 & 0.37 & - & Green Rust Fe(III) & 30.1 \\
\hline \multirow[t]{4}{*}{ Formate (sulfate) } & 77 & 1.26 & 2.85 & - & Green Rust Fe(II) & 68.1 \\
\hline & - & 0.47 & 0.40 & - & Green Rust Fe(III) & 31.9 \\
\hline & 13 & 1.26 & 2.82 & - & Green Rust Fe(II) & 67.6 \\
\hline & 13 & 0.47 & 0.41 & - & Green Rust Fe(III) & 32.4 \\
\hline \multirow[t]{4}{*}{ Lactate (chloride) } & 77 & 1.27 & 2.85 & - & Green Rust Fe(II) & 66.7 \\
\hline & - & 0.47 & 0.41 & - & Green Rust Fe(III) & 33.3 \\
\hline & 13 & 1.27 & 2.82 & - & Green Rust Fe(II) & 69.4 \\
\hline & - & 0.48 & 0.38 & - & Green Rust Fe(III) & 30.6 \\
\hline \multirow[t]{4}{*}{ Lactate (sulfate) } & 77 & 1.26 & 2.89 & - & Green Rust Fe(II) & 61.9 \\
\hline & - & 0.45 & 0.46 & - & Green Rust Fe(III) & 38.1 \\
\hline & 13 & 1.26 & 2.88 & - & Green Rust Fe(II) & 58.8 \\
\hline & - & 0.41 & 0.51 & - & Green Rust Fe(III) & 41.2 \\
\hline \multirow[t]{8}{*}{ NAG (chloride) } & 77 & 1.36 & 2.05 & - & Siderite & 17.7 \\
\hline & - & 1.27 & 2.88 & - & Green Rust Fe(II) & 47.4 \\
\hline & - & 0.48 & 0.42 & - & Green Rust Fe(III) & 13.2 \\
\hline & - & 0.49 & 0.6 & - & Lepidocrocite & 21.4 \\
\hline & 13 & 1.33 & 2.09 & 16.8 & Siderite & 14.7 \\
\hline & - & 1.28 & 2.84 & - & Green Rust Fe(II) & 46.4 \\
\hline & - & 0.5 & 0.4 & - & Green Rust Fe(III) & 18.3 \\
\hline & - & 0.49 & 0.03 & 45.3 & Lepidocrocite & 20.6 \\
\hline \multirow[t]{6}{*}{ NAG (sulfate) } & 77 & 1.35 & 2.04 & - & Siderite & 20.9 \\
\hline & - & 1.27 & 2.91 & - & Green Rust Fe(II) & 50 \\
\hline & - & 0.42 & 0.55 & - & Green Rust Fe(III) & 29.1 \\
\hline & 13 & 1.35 & 2.1 & 16.8 & Siderite & 29.4 \\
\hline & - & 1.28 & 2.91 & - & Green Rust Fe(II) & 41.5 \\
\hline & - & 0.43 & 0.56 & - & Green Rust Fe(III) & 29.1 \\
\hline \multirow[t]{5}{*}{ Pyruvate (chloride) } & 77 & 1.36 & 2.11 & - & Siderite & 38.7 \\
\hline & - & 1.33 & 2.76 & - & Siderite 2 & 33.8 \\
\hline & - & 0.48 & 0.56 & - & Lepidocrocite & 27.5 \\
\hline & 13 & - & - & - & $1-$ & - \\
\hline & & \multicolumn{5}{|c|}{ No quantitation can be made-siderite and lepidocrocite present } \\
\hline \multirow[t]{5}{*}{ Pyruvate (sulfate) } & 77 & 1.36 & 2.09 & - & Siderite & 38.7 \\
\hline & - & 1.33 & 2.79 & - & Siderite 2 & 30.6 \\
\hline & - & 0.48 & 0.57 & - & Lepidocrocite & 30.7 \\
\hline & 13 & - & - & - & $1-$ & - \\
\hline & & \multicolumn{5}{|c|}{ No quantitation can be made-siderite and lepidocrocite present } \\
\hline \multirow{5}{*}{ Serine (chloride) } & 77 & 1.36 & 2.08 & - & Siderite & 43 \\
\hline & - & 1.33 & 2.77 & - & Siderite 2 & 33.3 \\
\hline & - & 0.48 & 0.56 & - & Lepidocrocite & 23.6 \\
\hline & 13 & - & - & - & - & - \\
\hline & & \multicolumn{5}{|c|}{ No quantitation can be made-siderite and lepidocrocite present } \\
\hline Serine (sulfate) & 77 & 1.36 & 2.08 & - & Siderite & 43 \\
\hline & - & 1.33 & 2.77 & - & Siderite 2 & 33.3 \\
\hline & - & 0.48 & 0.56 & - & Lepidocrocite & 23.6 \\
\hline & 13 & - & - & - & $1-$ & - \\
\hline & & & dantitation & made- & and lepidocrocite $p$ & \\
\hline $\mathrm{H}_{2}$ (chloride) & 77 & 1.23 & 2.87 & - & Green Rust Fe(II) & 19.9 \\
\hline & - & 0.43 & 0.53 & - & Green Rust Fe(III) & 7.7 \\
\hline & - & 0.5 & 0.6 & - & Lepidocrocite & 72.4 \\
\hline & 13 & - & & & & \\
\hline & & & antitation $\mathrm{c}$ & ade- & st and lepidocrocite & \\
\hline $\mathrm{H}_{2}$ (carbonate) & 77 & 1.25 & 2.78 & - & Green Rust Fe(II) & 32.2 \\
\hline & - & 0.5 & 0.37 & - & Green Rust Fe(III) & 18.7 \\
\hline & - & 0.49 & 0.62 & - & Lepidocrocite & 49.1 \\
\hline & 13 & 1.27 & 2.85 & - & Green Rust Fe(II) & 8.5 \\
\hline & - & 0.48 & 0.38 & - & Green Rust Fe(III) & 3.3 \\
\hline & - & 0.50 & 0.01 & 45.3 & Lepidocrocite & 88.2 \\
\hline $\mathrm{H}_{2}$ (sulfate) & 77 & 1.28 & 2.88 & - & Green Rust Fe(II) & 16.1 \\
\hline & - & 0.49 & 0.41 & - & Green Rust Fe(III) & 19.0 \\
\hline & - & 0.49 & 0.59 & - & Lepidocrocite & 65.0 \\
\hline & 13 & - & - & - & $1-$ & - \\
\hline & & & quantitatic & $\mathrm{e}$ mad & ominantly lepidocro & \\
\hline
\end{tabular}



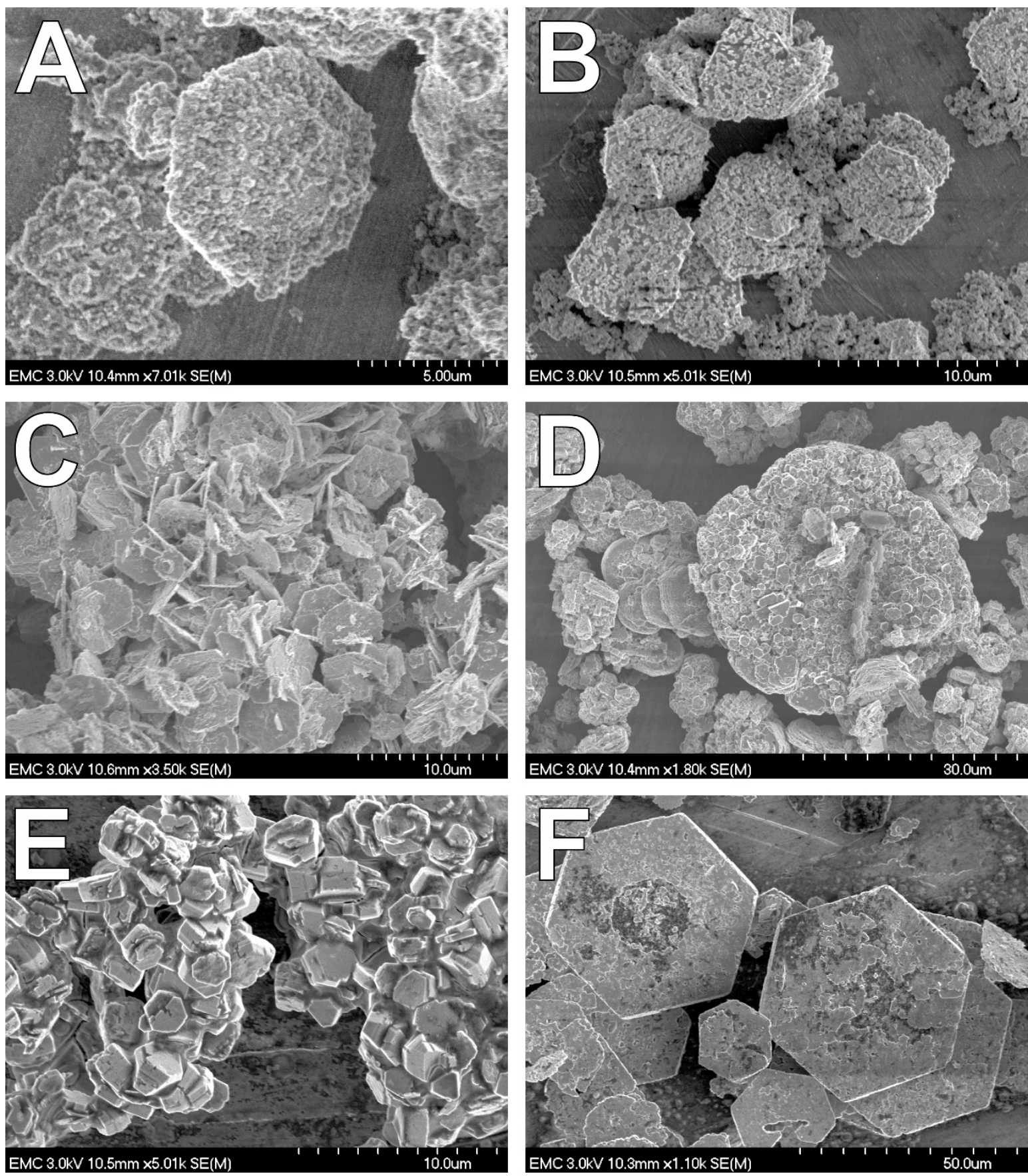

Figure 4. SEM images of solids at the end of the incubations containing $\mathrm{H}_{2}$ with sulfate $(\mathbf{A}), \mathrm{H}_{2}$ with carbonate (B), formate with chloride (C), formate with sulfate (D), lactate with chloride (E), and lactate with sulfate $(\mathbf{F})$. 
Table 3. Identification of secondary minerals.

\begin{tabular}{|c|c|c|c|}
\hline System & pXRD & Mössbauer & SEM \\
\hline Formate (chloride) & $\mathrm{GR}_{\mathrm{C}}{ }^{a}$ & GR & GR \\
\hline Formate (sulfate) & $\mathrm{GR}_{\mathrm{C}}$ & GR & GR \\
\hline $\mathrm{H}_{2}$ abiotic & $\mathrm{GR}_{\mathrm{C}}$ & ND & ND \\
\hline $\mathrm{H}_{2}$ (carbonate) & $\mathrm{GR}_{\mathrm{C}}$ & GR & GR \\
\hline $\mathrm{H}_{2}$ (sulfate) & $\mathrm{GR}_{\mathrm{S}}{ }^{a}$ & GR & GR \\
\hline $\mathrm{H}_{2}$ (chloride) & $\mathrm{GR}_{\mathrm{C}}$ & GR & GR \\
\hline Lactate (chloride) & $\mathrm{GR}_{\mathrm{C}}$ & GR & GR \\
\hline Lactate (sulfate) & $\mathrm{GR}_{\mathrm{C}}, \mathrm{GR}_{\mathrm{S}}$ & GR & GR \\
\hline NAG (chloride) & $\mathrm{GR}_{\mathrm{C}}, \mathrm{Sid}^{b}$ & GR, Sid & GR, Sid \\
\hline NAG (sulfate) & $\mathrm{GR}_{\mathrm{C}}, \mathrm{GR}_{\mathrm{S}}, \mathrm{Sid}$ & GR, Sid & GR, Sid \\
\hline Pyruvate (chloride) & Sid & Sid & Sid \\
\hline Pyruvate (sulfate) & Sid & Sid & Sid \\
\hline Serine (chloride) & Sid & Sid & Sid \\
\hline Serine (sulfate) & Sid & Sid & Sid \\
\hline
\end{tabular}

\subsection{Formate}

Formate essentially served as a positive control given that we have previously shown that formate is utilized as an electron donor for DIR by S. putrefaciens CN32 [16,28,44,55,63]. The initial production of $2.3 \mathrm{mM} \mathrm{Fe}$ (II) within the first $24 \mathrm{~h}$ was followed by a lag period lasting 13 days in the chloride-amended system, after which there was vigorous and sustained Fe(II) production concurrent with formate consumption (Figure 5). The reduction of $\mathrm{Fe}(\mathrm{III})$ was essentially complete (i.e., there was no change in $\mathrm{Fe}(\mathrm{II})$ concentrations) by day 55 . The systems were not explicitly buffered (i.e., a buffer was not a component of the DMM) and the $\mathrm{pH}$ increased from 7.5 to 8.3 within $18 \mathrm{~h}$ after inoculation followed by a slower $\mathrm{pH}$ increase, ultimately reaching $\mathrm{pH} 9.1$ by day 62 (Figure 5). The bioreduction of lepidocrocite in the sulfate-amended systems followed similar trends with respect to $\mathrm{Fe}$ (II) production, formate consumption and $\mathrm{pH}$, but with a longer lag period (Figure 5) and slower rate of total $\mathrm{Fe}(\mathrm{II})$ production (Table 1). Analysis of the solids by pXRD (Figure 6) and Mössbauer spectroscopy (Table 2) indicates complete removal of lepidocrocite accompanied by the formation of green rust. Carbonate green rust was the only secondary mineral observed in the chloride-amended system (Figure 6), present as platy hexagonal particles up to $5 \mu \mathrm{m}$ across, often with well-defined edges (Figure $4 \mathrm{C}$ ). In the sulfate-amended systems, indications of sulfate green rust were observed by day 9 , by day 15 both sulfate and carbonate green rust were present, and by day 62 only carbonate green rust was detected (Figure 6). Unlike the generally well-formed crystallites in the chloride-amended system, the green rust particles in the sulfate-amended system were highly irregular, both in terms of width as well as the morphology of the crystal edges (Figure 4D). 


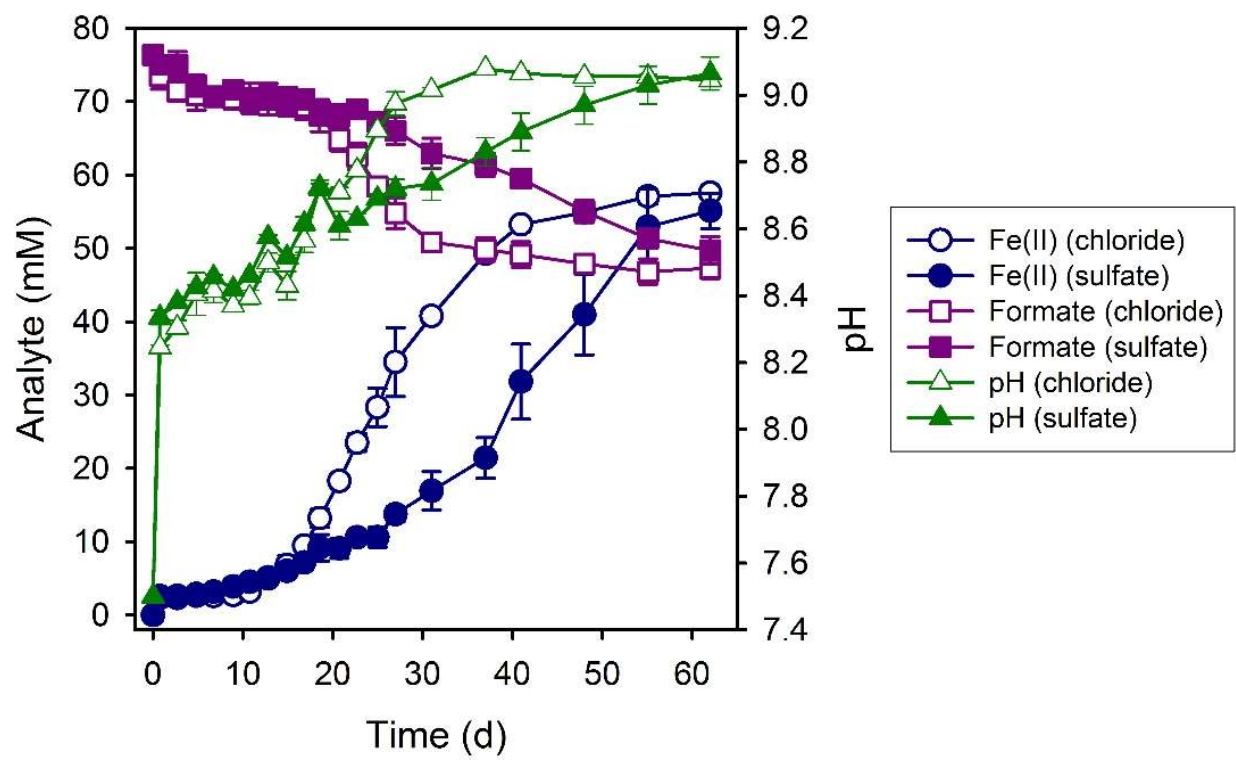

Figure 5. Fe(II) production, formate consumption, and $\mathrm{pH}$ during the bioreduction of lepidocrocite by S. putrefaciens CN32 with formate as the electron donor.
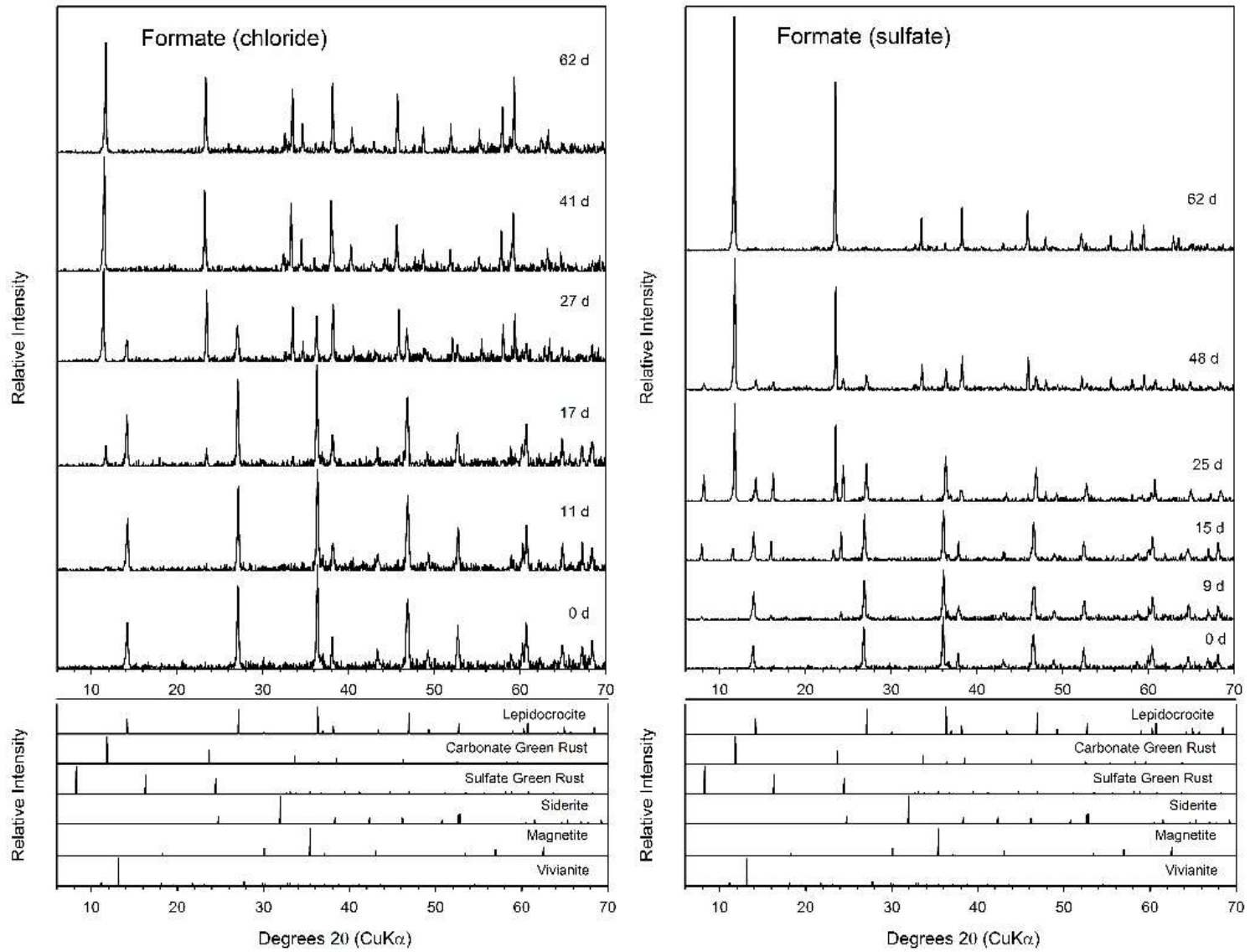

Figure 6. pXRD analysis of the solids in the systems with formate as the electron donor amended with chloride (left) or sulfate (right). 


\subsection{Lactate}

As observed with formate, there was an initial increase in $\mathrm{pH}$ from 7.5 to 8.2 and a pulse of $\mathrm{Fe}(\mathrm{II})$ production $(\sim 4 \mathrm{mM})$ within the first $24 \mathrm{~h}$, that was followed by a lag in Fe(II) production lasting $\sim 27$ days and $\sim 17$ days in the chloride- and sulfate-amended systems, respectively (Figure 7). After the corresponding lag periods, Fe(II) production proceeded at similar rates (Table 1) in each system leading to production of 56 and $59 \mathrm{mM}$ total Fe(II) in the chloride- and sulfate-amended systems, respectively. Unlike the formate systems, there was no further increase in $\mathrm{pH}$ after the initial rise; indeed, by day 62 the $\mathrm{pH}$ decreased to 8.0 in the chloride-amended system (Figure 7). Lactate consumption was concurrent with Fe(II) and acetate production. At the end of the experiment (day 62) both pXRD and Mössbauer spectroscopy showed complete loss of lepidocrocite and formation of green rust (Table 2 and Figure 8). Carbonate green rust was the only secondary mineral observed in the chloride-amended system (Figure 8 ) and the crystallites were 1-2 $\mu \mathrm{m}$ thick and up to $2 \mu \mathrm{m}$ wide and nominally hexagonal (Figure 4E). In the sulfate-amended systems, indications of sulfate green rust were observed by day 7 , and by day 17 both sulfate and carbonate green rust were present (Figure 8); unlike the sulfate-amended formate system, both sulfate and carbonate green rust were present at the end of the experiment (day 62). The green rust crystallites in the sulfate-amended system were exceptionally wide (up to $50 \mu \mathrm{m}$ ), thin hexagonal plates with very well-formed edges (Figure $4 \mathrm{~F}$ ).

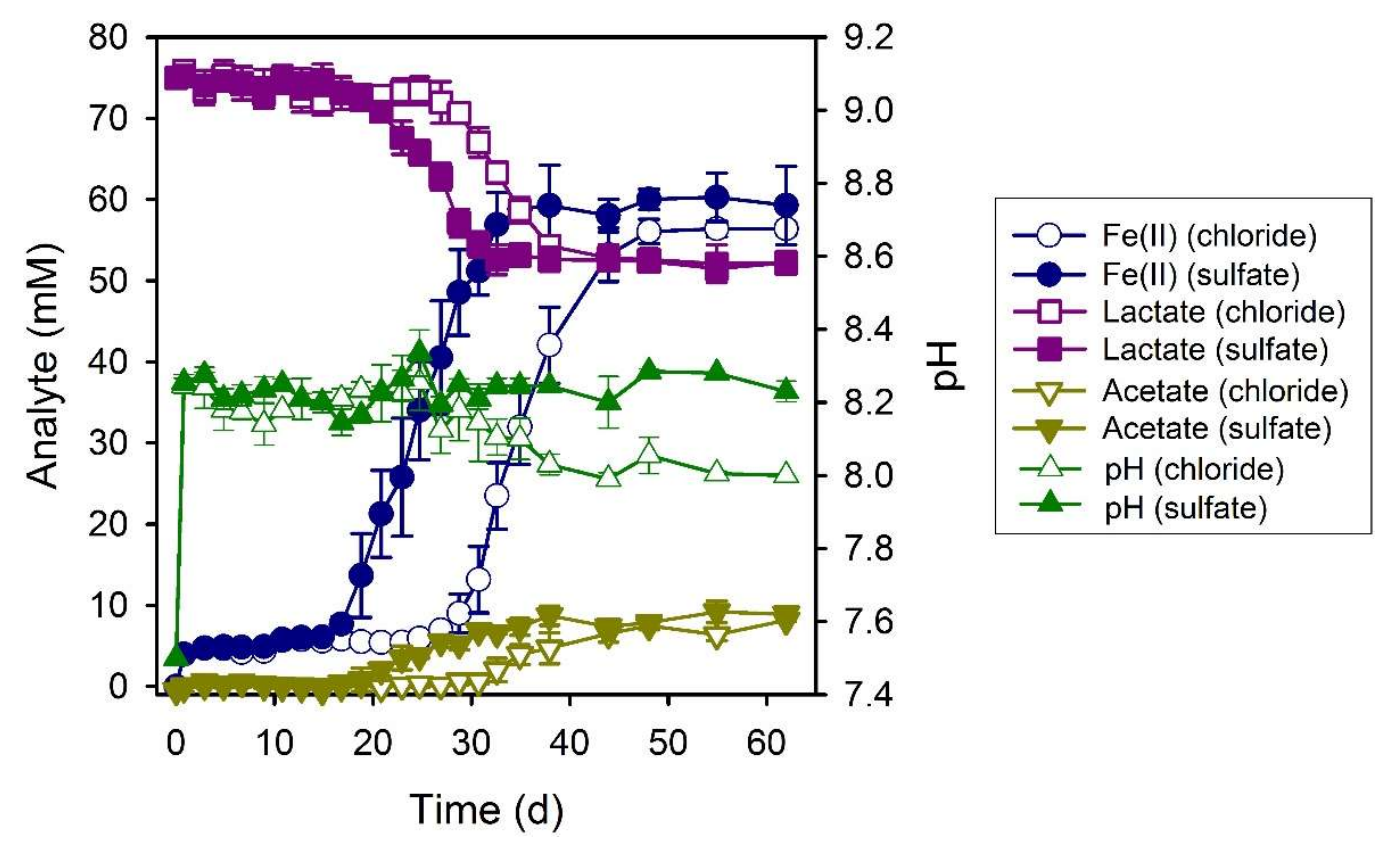

Figure 7. Fe(II) and acetate production, lactate consumption, and $\mathrm{pH}$ during the bioreduction of lepidocrocite by S. putrefaciens CN32 with lactate as the electron donor. 

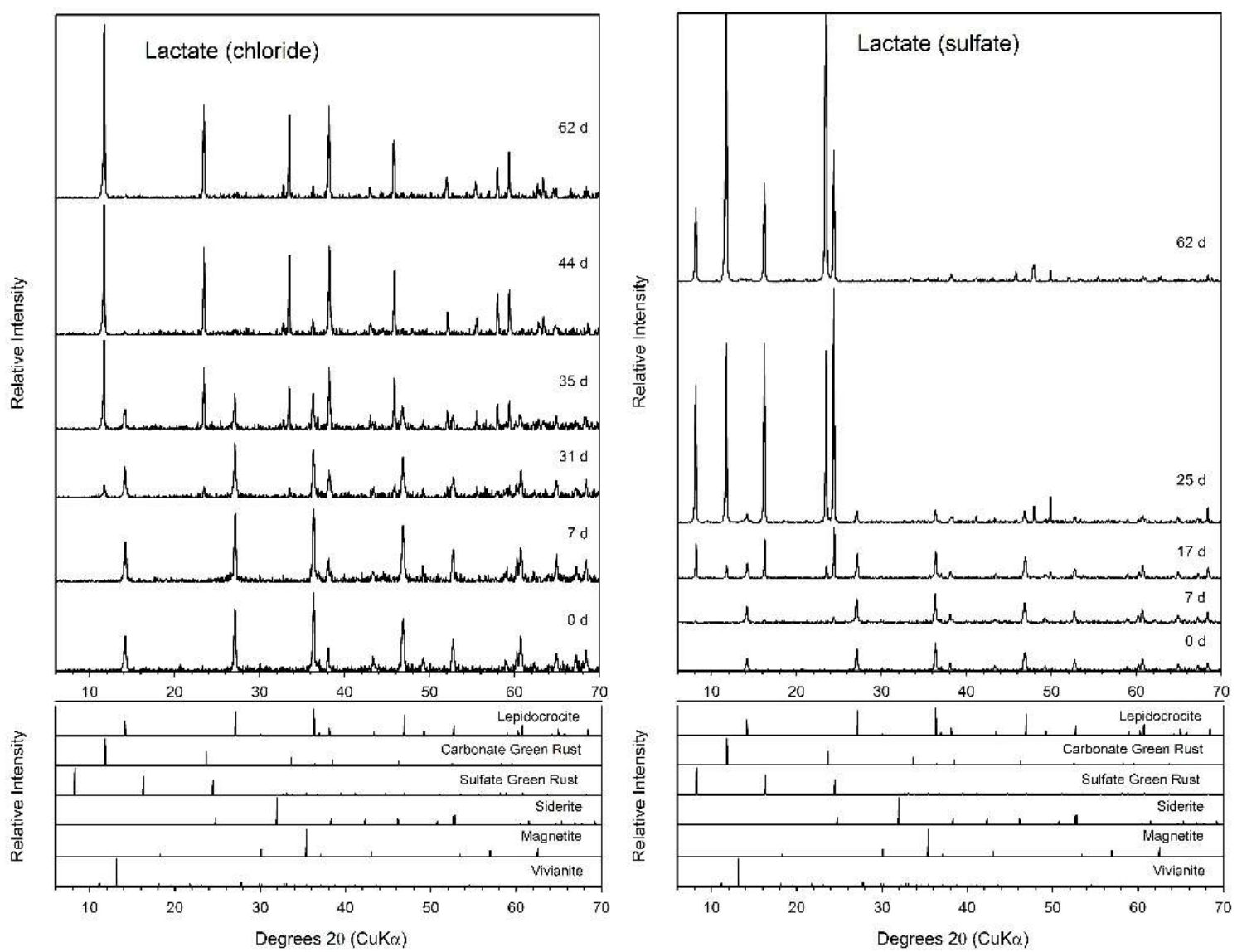

Figure 8. pXRD analysis of the solids in the systems with lactate as the electron donor amended with chloride (left) or sulfate (right).

\subsection{N-Acetylglucosamine (NAG)}

Within the first $24 \mathrm{~h}$ after inoculation, $\sim 3 \mathrm{mM}$ Fe(II) was produced in the chloride-amended system and there was minimal change over the next 24 days (Figure 9). Substantial Fe(II) production was observed between day 25 and day 76 leading to an accumulation of $\sim 61 \mathrm{mM} \mathrm{Fe}(\mathrm{II})$ at the termination of the experiment at day 106; at which time pXRD and Mössbauer spectroscopy indicated the presence of residual lepidocrocite and secondary minerals siderite and carbonate green rust (Table 2 and Figure 10). Carbonate green rust formation was not evident until 38 days after inoculation and siderite was not observed until day 69 (Figure 10). The Fe(II) production profile was more complex in the sulfate-amended system (Figure 9). As with the chloride system, there was an initial production of $\mathrm{Fe}(\mathrm{II})$ within the first $24 \mathrm{~h}(\sim 4 \mathrm{mM})$, but this was followed by a much shorter lag period ( 3 days), after which the Fe(II) concentration increased to $14 \mathrm{mM}$ at day 25 and remained essentially unchanged until $\mathrm{Fe}(\mathrm{II})$ production resumed at day 31. At 106 days after inoculation, the $\mathrm{Fe}(\mathrm{II})$ concentration reached $71 \mathrm{mM}$, at which point lepidocrocite was no longer detected by Mössbauer or pXRD (Table 2 and Figure 10). Sulfate green rust formation was first observed at 7 days after inoculation, followed by the appearance of carbonate green rust at day 38 and siderite at day 69 (Figure 10). In both systems, Fe(II) production was accompanied by consumption of NAG and accumulation of acetate and after an initial increase in $\mathrm{pH}$ to $\sim 8.1$, the $\mathrm{pH}$ gradually decreased to $\sim 7.6$ by day 106 (Figure 9). The morphology of green rust crystallites were similar in both chloride- and sulfate-amended systems; thin hexagonal particles with irregular edges up to $20 \mu \mathrm{m}$ wide decorated with anhedral to subhedral $0.5-2 \mu \mathrm{m}$ rhombic siderite crystallites (Figure 11A,B). 

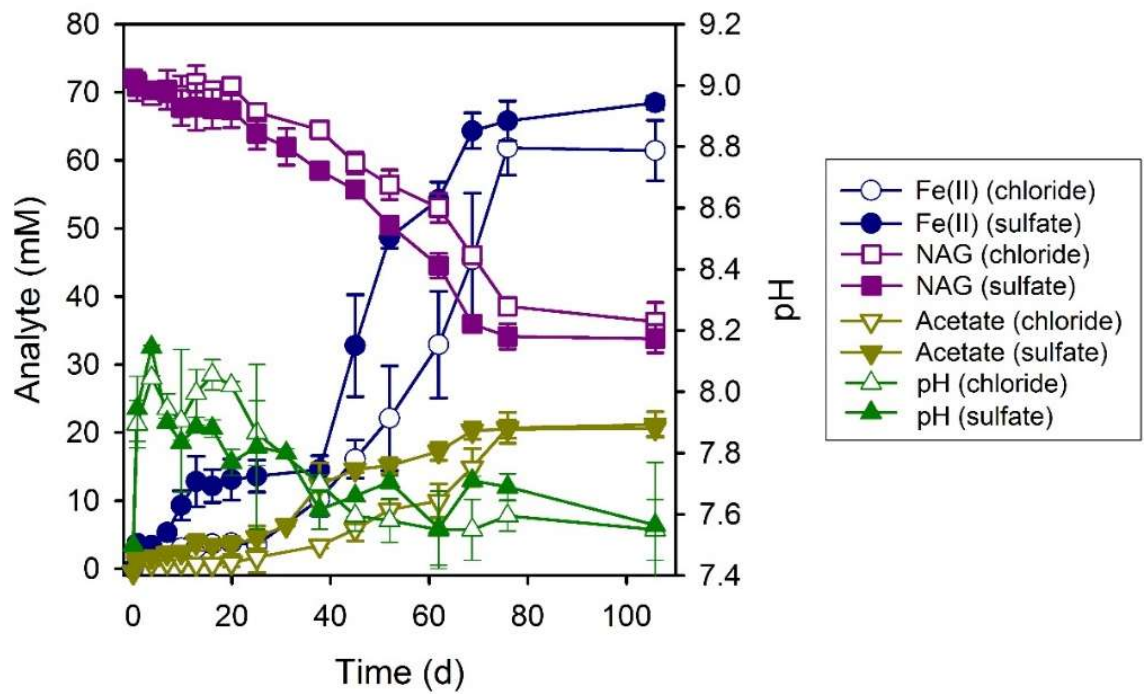

Figure 9. $\mathrm{Fe}(\mathrm{II})$ and acetate production, $\mathrm{N}$-acetylglucosamine (NAG) consumption, and $\mathrm{pH}$ during the bioreduction of lepidocrocite by S. putrefaciens CN32 with NAG as the electron donor.
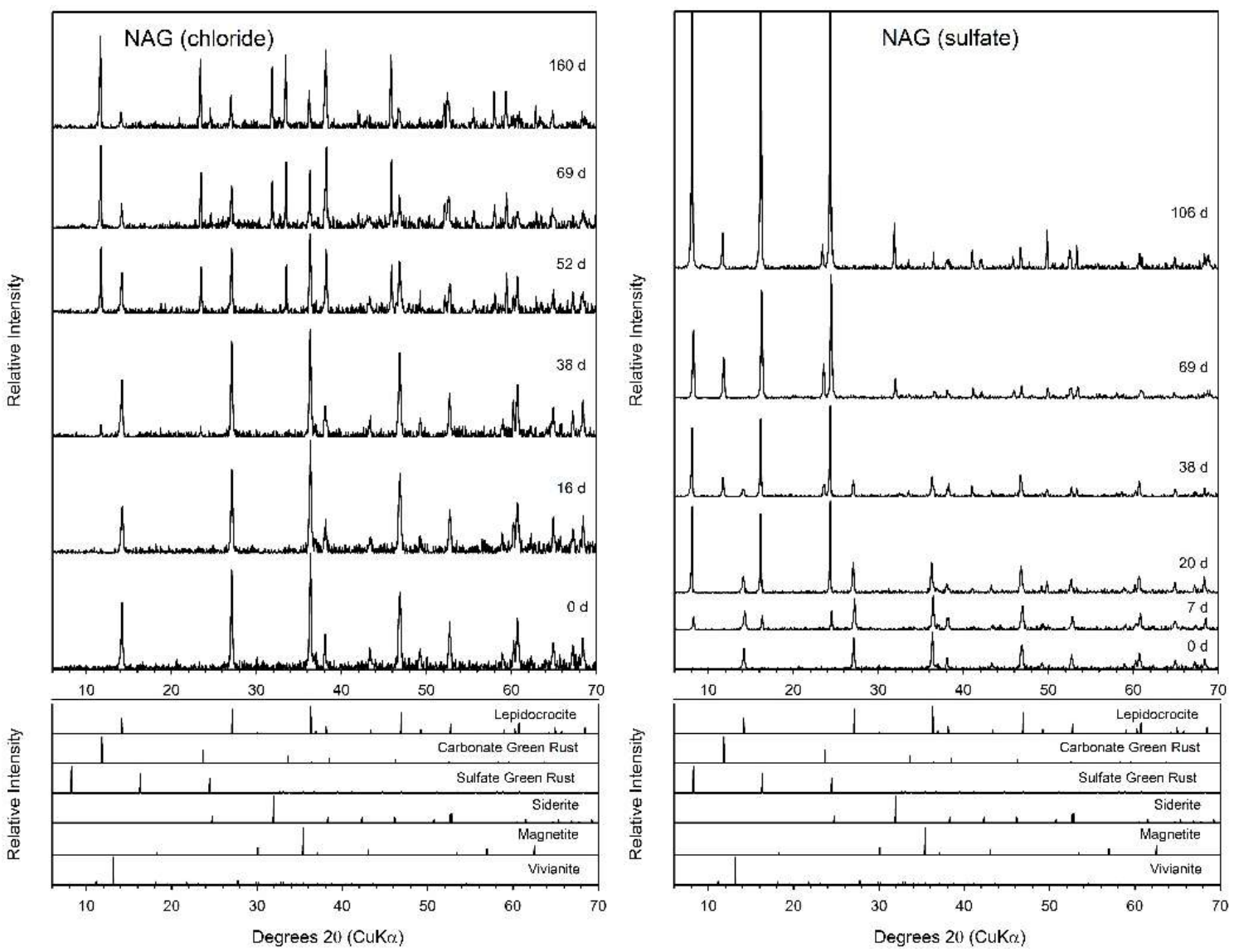

Figure 10. pXRD analysis of the solids in the systems with $N$-acetylglucosamine (NAG) as the electron donor amended with chloride (left) or sulfate (right). 

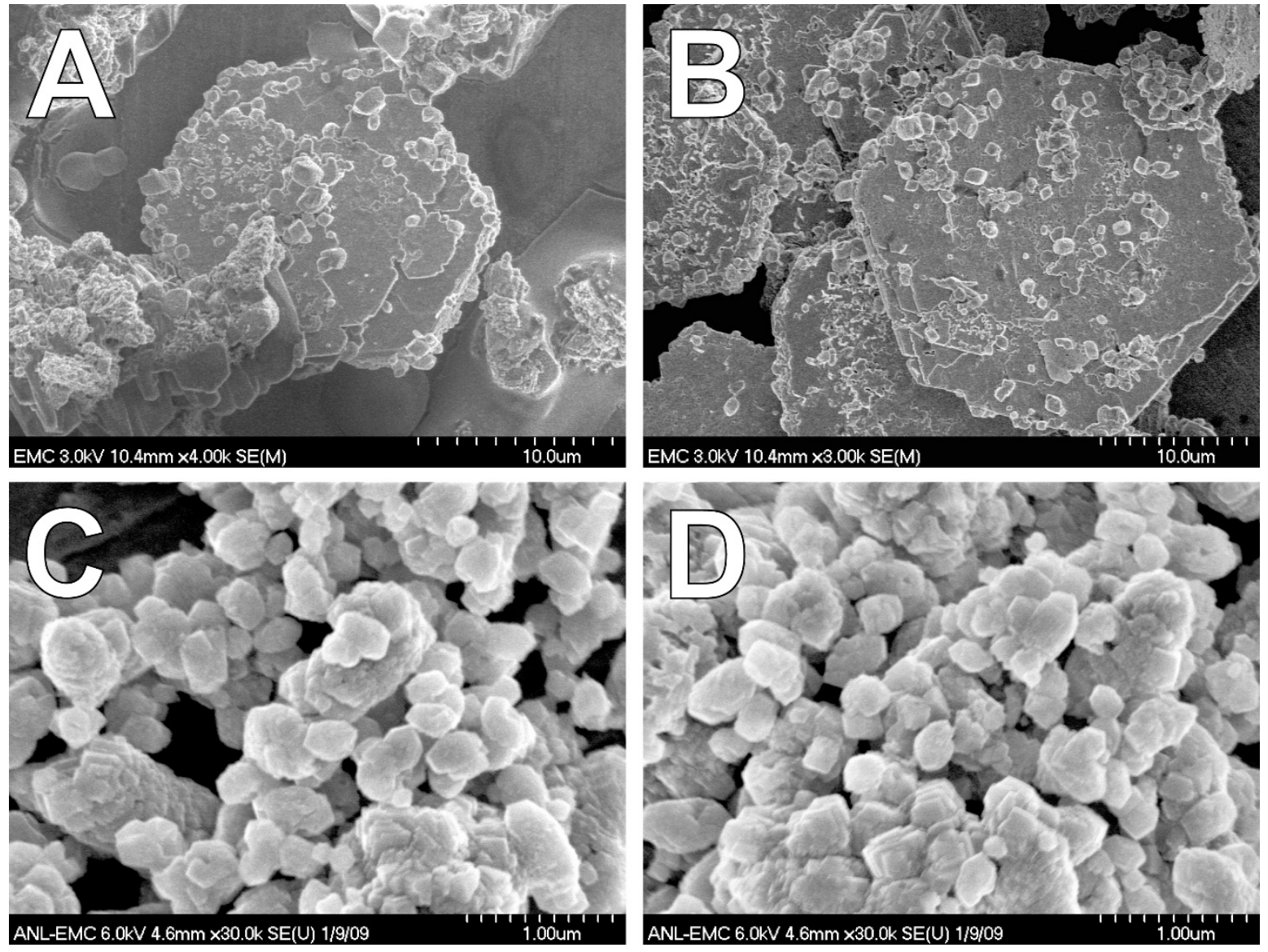

Figure 11. SEM images of solids at the end of the incubations containing $N$-acetylglucosamine (NAG) with chloride (A), NAG with sulfate (B), pyruvate with sulfate (C), and serine with sulfate (D).

\subsection{Pyruvate}

Compared to formate, lactate, and NAG, the initial Fe(II) production was higher with pyruvate $(7 \mathrm{mM}$ within $6.5 \mathrm{~h}$ ) and the overall bioreduction of lepidocrocite was substantially faster, with $>90 \%$ of the total $\mathrm{Fe}(\mathrm{II})$ production occurring within the first 10 days; both the chloride- and sulfate-amended systems followed essentially the same trajectory (Figure 12). Fe(II) production was accompanied by complete depletion of pyruvate and accumulation of acetate. The $\mathrm{pH}$ varied considerably over the course of the experiment. Within $6 \mathrm{~h}$ of inoculation, the $\mathrm{pH}$ increased from 7.5 to 8.0, followed by a decrease to 7.1 over the next $66 \mathrm{~h}$, a rebound to $\mathrm{pH} 8$ by day 6 , and a gradual increase to a final $\mathrm{pH}$ of 8.5 by day 106 (Figure 12). The solids remaining at the end of the experiment consisted of residual lepidocrocite and siderite (Table 2 and Figure 13); there were no indications of green rust formation at any point during the experiment (data not shown). Siderite was present as anhedral to subhedral imperfect rhombohedral crystallites, typically 1-3 $\mu \mathrm{m}$ and often highly aggregated/cemented (Figure 11C). 


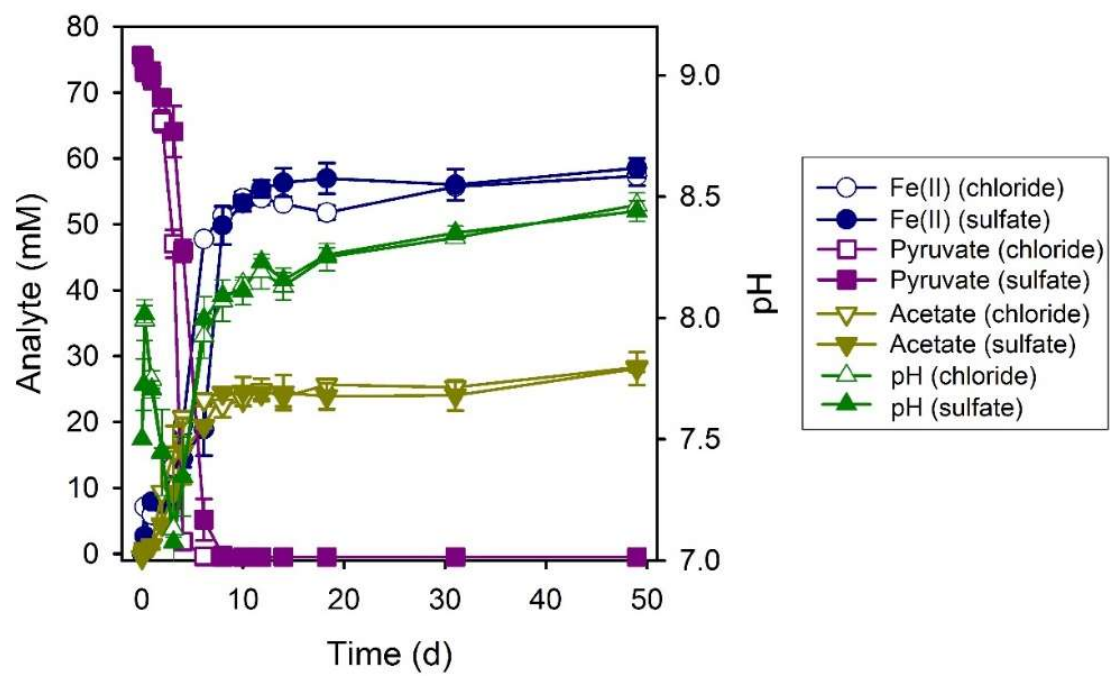

Figure 12. Fe(II) and acetate production, pyruvate consumption, and $\mathrm{pH}$ during the bioreduction of lepidocrocite by S. putrefaciens CN32 with pyruvate as the electron donor.

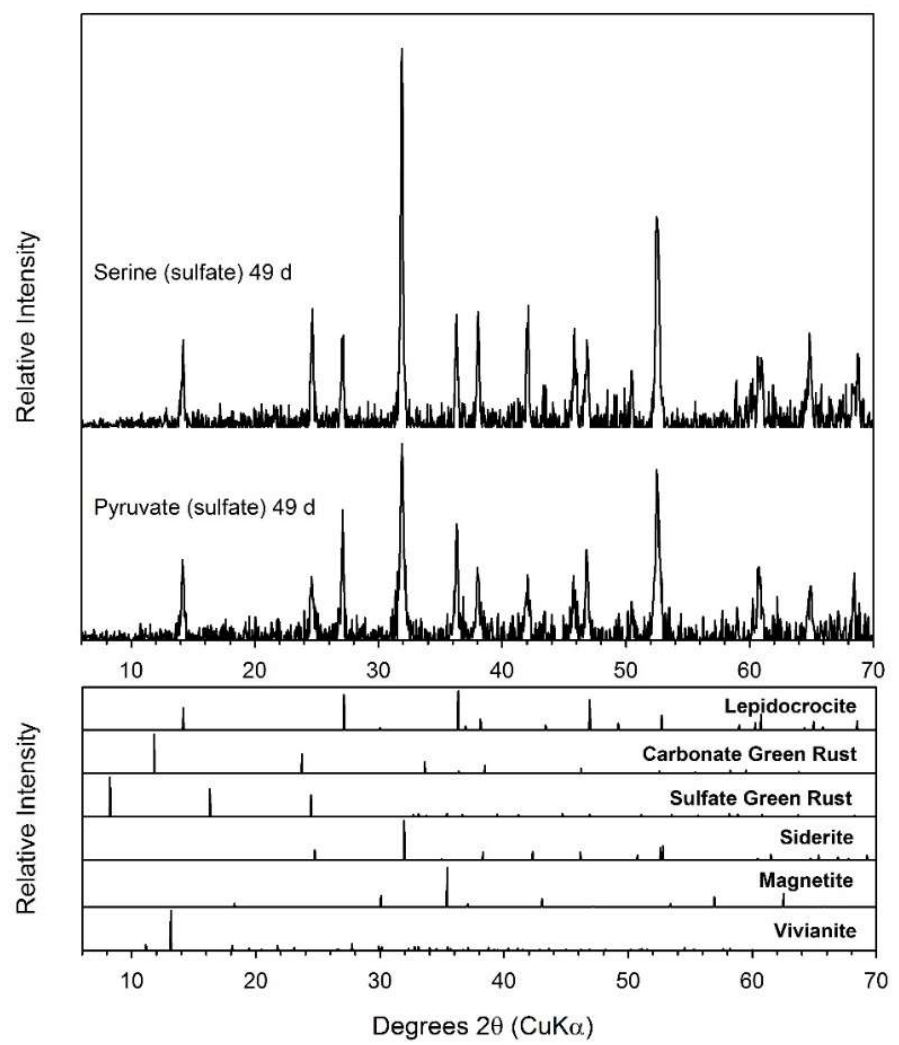

Figure 13. pXRD analysis of the solids in the sulfate-amended systems with pyruvate or serine as the electron donor.

\subsection{Serine}

The bioreduction of lepidocrocite by S. putrefaciens CN32 was immediate and sustained when serine was provided as the electron donor; nearly $90 \%$ of $\mathrm{Fe}(\mathrm{II})$ production occurred within the first 10 days in both the chloride- and sulfate-amended systems (Figure 14). We were unable to measure serine concentrations, but $\mathrm{Fe}$ (II) production was concurrent with acetate production, and pyruvate was observed as a transient species. As with pyruvate, the $\mathrm{pH}$ in the serine systems was variable over the course of the experiment, with final $\mathrm{pH}$ values of 8.2 and 8.5 in the chloride- and sulfate-amended systems, respectively. In both systems the solids at the conclusion of the experiment consisted of 
residual lepidocrocite and siderite (Table 2 and Figure 13). The morphology of siderite particles formed in the serine systems were identical to those in the pyruvate systems (Figure 11C,D).

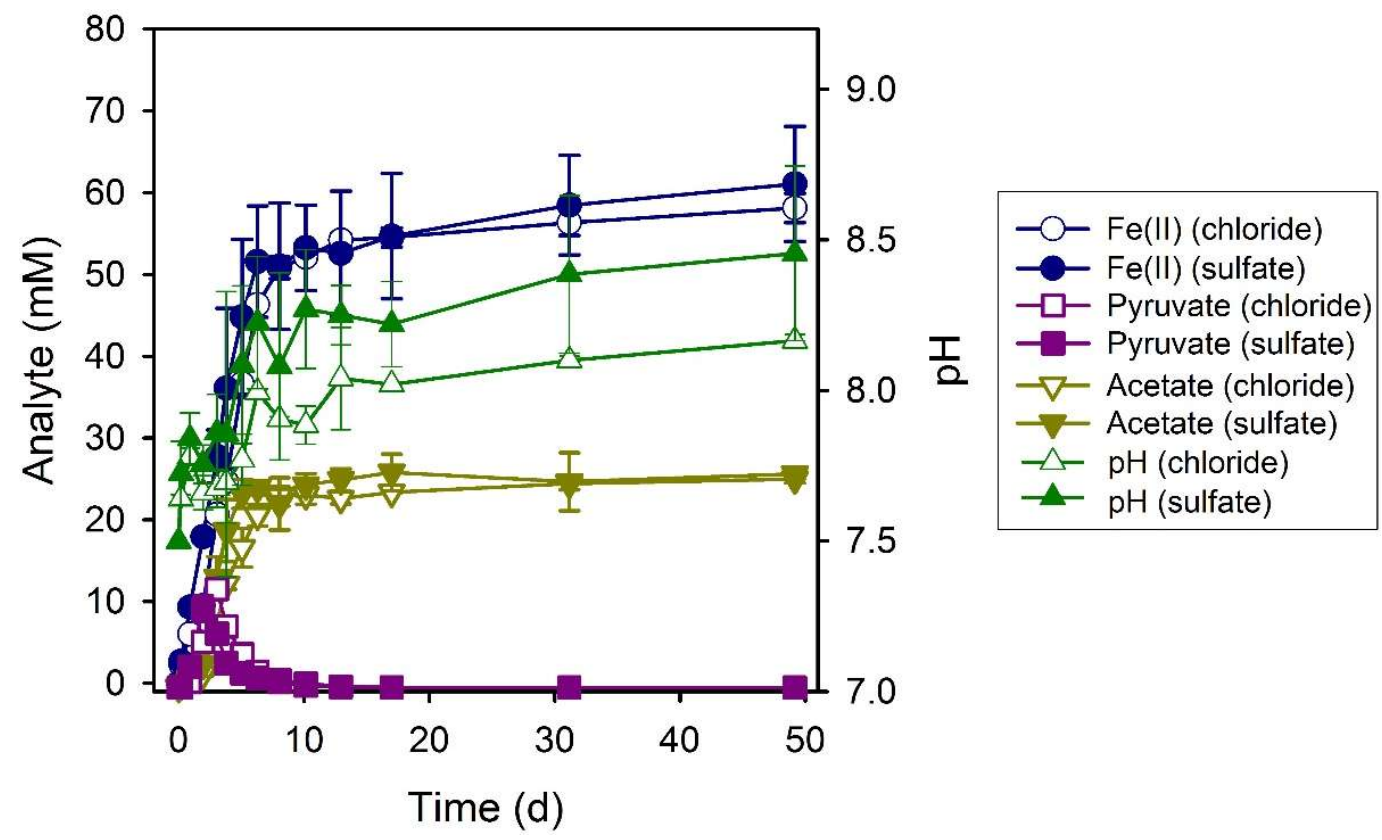

Figure 14. Fe(II), acetate, and pyruvate production/consumption and $\mathrm{pH}$ during the bioreduction of lepidocrocite by $S$. putrefaciens $\mathrm{CN} 32$ with serine as the electron donor.

\section{Discussion}

\subsection{Electron Donor Utilization and Dissimilatory Iron(III) Reduction}

The genus Shewanella consists of a phenotypically diverse group of over 50 species found widely distributed in a broad range of aquatic (lacustrine and marine) and terrestrial environments [64-66]. Under oxic conditions, members of the genus can utilize a broad range of $\mathrm{C}_{1-3}$ aliphatic acids, amino acids, sugars, peptides, and nucleotides [65,67-69], but only a limited subset are utilized as electron donors for anaerobic respiration [70]. Among the 17 putative electron donors we tested with $S$. putrefaciens $\mathrm{CN} 32$, only $\mathrm{H}_{2}$, formate, lactate, pyruvate, serine, and NAG supported anaerobic respiration with AQDS/Fe(III) oxide as the terminal electron acceptor(s).

The ability to use $\mathrm{H}_{2}$ as an electron donor for DIR is broadly represented within Shewanella [71-76]. In this study, reduction of Fe(III) by $S$. putrefaciens CN32 was rapid within the first 2 days, then quickly plateaued to approximately 5, 10, and $15 \mathrm{mM} \mathrm{Fe(II)} \mathrm{in} \mathrm{the} \mathrm{chloride,} \mathrm{sulfate,} \mathrm{and} \mathrm{carbonate} \mathrm{systems,}$ respectively. The limited extent of $\mathrm{Fe}(\mathrm{III})$ reduction is not due to electron donor limitation as the systems initially contained $>20 \mathrm{mmol} \mathrm{H}_{2}$ and only $4 \mathrm{mmol} \mathrm{Fe(III)} \mathrm{(50} \mathrm{mL} \mathrm{of} 80 \mathrm{mM} \mathrm{Fe}(\mathrm{III})$ ). It is possible that hydrogen may have escaped from the bottle, thus limiting Fe(III) reduction; however, replenishing the hydrogen headspace did not result in significant additional Fe(II) production. Likewise, the limited Fe(II) production cannot be explained by a decrease in cell viability over time as reinoculation with freshly grown $S$. putrefaciens CN32 resulted in no increase in Fe(II). Furthermore, the production of $\sim 60 \mathrm{mM} \mathrm{Fe}(\mathrm{II})$ within 4 days in the abiotic control (i.e., $\mathrm{H}_{2} / \mathrm{Pd} / \mathrm{AQDS}$ as a surrogate for microbial reduction) suggests that there was no thermodynamic limitation on the system. Limited reduction of Fe(III) was also observed during DIR of $\gamma$-FeOOH by S. putrefaciens CIP $8040^{\mathrm{T}}$ with $\mathrm{H}_{2}$ as the electron donor [76].

Formate and lactate are established electron donors for DIR by S. putrefaciens CN32 [25,33,44,48] as well as Shewanella spp. in general [16,34,46,52,53,71-75,77]. Consumption of formate by S. putrefaciens CN32 was directly linked to Fe(II) production. Approximately 2 moles of Fe(II) produced for each mole of formate consumed (Table 1) by S. putrefaciens CN32, consistent with the stoichiometry of formate 
oxidation to carbon dioxide (formate $\rightarrow \mathrm{CO}_{2}=2 e^{-}$) (Table 1). In the case of lactate, 2.5 moles of Fe(II) was produced per mole of lactate consumed, which is substantially less than 4 moles of Fe(II) per mole of lactate based on the oxidation of lactate to acetate and carbon dioxide (lactate $\rightarrow$ acetate $+\mathrm{CO}_{2}=$ $\left.4 e^{-}\right)$. In addition, the accumulation of acetate was less than expected based on the amount of lactate consumed (Table 1). Acetate is not used by S. putrefaciens CN32 as an electron donor for DIR, but it may have used some acetate as a $C$ source (as could a portion of the lactate consumed).

Compared with formate and lactate, the anaerobic metabolism of pyruvate by Shewanella spp. is more complex. In addition to serving as an electron donor for DIR [52,53,71,72,74,75], several Shewanella spp. are reported to ferment pyruvate. Fermentation of pyruvate by Shewanella oneidensis MR-1 produces acetate, lactate, formate, and $\mathrm{H}_{2}$ [78] and fermentation by Shewanella profunda produces acetate, lactate, and succinate [79]. S. putrefaciens ATCC 8071 (formerly Alteromonas putrefaciens) used pyruvate as an electron donor for DIR resulting in oxidation to acetate and carbon dioxide (pyruvate $\rightarrow$ acetate $+\mathrm{CO}_{2}=2 e^{-}$) and stoichiometric production of $\mathrm{Fe}(\mathrm{II})$ [72]. However, pyruvate utilization by S. putrefaciens W3-18-1 in the presence of Fe(III) oxide likely involved fermentation of pyruvate, and use of pyruvate and pyruvate fermentation products (e.g., formate) as electron donors for DIR [53]. Our results suggest that a similar dynamic occurred with $S$. putrefaciens CN32 in our experimental systems containing pyruvate; if pyruvate was only utilized as an electron donor for DIR, only $30 \mathrm{mM}$ would be needed to account for the $\sim 60 \mathrm{mM}$ of Fe(II) produced, yet all of the pyruvate $(75 \mathrm{mM})$ was consumed.

Few studies have explicitly examined individual amino acids as potential electron donors for anaerobic respiration. Serine, cysteine, glutamate, and aspartate are effective electron donors for anaerobic respiration by Alteromonas (Shewanllla) putrefaciens NCMB 1735 using trimethylamine oxide as the terminal electron acceptor [80]. Geovibrio ferrireducens can grow by coupling the oxidation of proline to the reduction of Fe(III) [6]. However, none of the amino acids tested by Lovley et al. [15] (glutamine, serine, arginine, leucine, proline, glutamate, tryptophan, and tyrosine) were used as electron donors for DIR by Geobacter metallireducens. Among the amino acids examined in this study (alanine, glutamate, glycine, and serine), only serine was an effective electron donor for DIR by S. putrefaciens CN32. We did not measure serine concentrations, but serine is easily converted to pyruvate, and pyruvate was observed as a transient intermediate during Fe(III) reduction. Moreover, the Fe(II) production rates in the serine-amended systems were only slightly slower than the rates in the pyruvate-amended systems (which had the fastest rates among the donors tested (Table 1)), consistent with conversion of serine to pyruvate and its subsequent utilization. This is the first report of serine serving as an electron donor for DIR.

NAG is a monomer of chitin, which is present in the cell walls of fungi and the cuticles and exoskeletons of arthropods, mollusks, and worms and is the second most abundant polymer in nature after cellulose. NAG is also a component of cell wall peptidoglycan in gram-positive and gram-negative bacteria. As a product of the microbial decomposition of chitin and peptidoglycan [81,82], NAG is an important component of the organic nitrogen pool in aquatic and terrestrial systems [83-85]. As both a C and N source, NAG is metabolized by a broad range of bacteria [84,86,87]. Many Shewanella spp. (including $S$. putrefaciens $\mathrm{CN} 32$ ) respire NAG aerobically [88,89] and several are able to use NAG as a substrate for fermentative growth $[88,90,91]$. Our study provides the first evidence that a Shewanella sp. can use NAG as an electron donor for DIR, an ability that has only been reported for Thermincola ferriacetica [92]. The production of Fe(II) was concurrent with NAG consumption and acetate production, which is consistent with NAG serving as an electron donor for Fe(III) reduction. NAG was not consumed independent of Fe(III) reduction suggesting that S. putrefaciens CN32 does not ferment NAG.

\subsection{Fe(II) Secondary Mineral Formation}

The presence of specific electron donors has been shown to have significant impacts on the development of microbial communities and the formation of Fe(II)-bearing minerals in laboratory based-experiments and in-situ studies in subsurface environments [52,53,93-96]. Likewise, in this 
study we observe that specific electrons donors lead to the formation specific Fe(II)-bearing secondary minerals during DIR of lepidocrocite by S. putrefaciens CN32.

Previous studies of the bioreduction of lepidocrocite have reported magnetite, siderite, vivianite, green rust, and chukanovite as Fe(II)-bearing secondary minerals, with the formation of specific phases attributed to several factors including the rate and extent of $\mathrm{Fe}(\mathrm{II})$ production, electron shuttles, the cell number, the extent of particle aggregation, and the presence of sorbates (e.g., oxyanions and DOC) $[16,34,41,43-45,49,55,63,97-99]$. Stoichiometric conversion to magnetite is often observed during the bioreduction of lepidocrocite $[41,44,45,49,63,98]$. However, magnetite was not observed as a secondary mineral in any of our experimental systems, likely due to trace levels of phosphate present in the lepidocrocite used in our experiments [63], as low levels of phosphate are known to suppress magnetite formation during DIR of Fe(III) oxides [28,33,44,47,63]. Vivianite formation requires the presence of substantial phosphate (e.g., vivianite was not observed at P:Fe rations lower than $0.08[33,43,48,63])$, and vivianite was not observed in any of our experimental systems ( $\mathrm{P}: \mathrm{Fe}=0.005[63])$. Chukanovite (ferrous hydroxy carbonate) was also not observed in any of our experimental systems. Chukanovite can perhaps be better described as a tertiary product of the DIR of Fe(III) oxides in that it is not observed as an initial product of $\mathrm{Fe}(\mathrm{III})$ oxide bioreduction, rather it forms later as a product of the reduction of $\mathrm{Fe}(\mathrm{II}) / \mathrm{Fe}(\mathrm{III})$ secondary minerals like magnetite and green rust $[28,37,41,44,49,63,100]$, and there may not have been sufficient time for chukanovite to form in our experimental systems.

Green rusts were observed as products of lepidocrocite bioreduction by S. putrefaciens CN32 when $\mathrm{H}_{2}$, formate, lactate, or NAG were provided as electron donors (Table 3). Green rusts are layered $\mathrm{Fe}(\mathrm{II})-\mathrm{Fe}(\mathrm{III})$ hydroxides having a pyroaurite-type structure-i.e., alternating positively charged $\mathrm{Fe}(\mathrm{II})-\mathrm{Fe}(\mathrm{III})$ hydroxide layers and hydrated anion layers having the general composition: $\left[\mathrm{Fe}^{\mathrm{II}}{ }_{4} \mathrm{Fe}^{\mathrm{III}}{ }_{2}\right.$ $\left.(\mathrm{OH})_{12}\right]^{2+}\left[(A)_{2 / n} y \mathrm{H}_{2} \mathrm{O}\right]^{2-}$, where $A$ is an $n$-valent anion (e.g., $\mathrm{Cl}^{-}, \mathrm{SO}_{4}{ }^{2-}$, or $\mathrm{CO}_{3}{ }^{2-}$ ) and $y$ denotes varying amounts of interlayer water ( $y=2$ to 4$)$. They are found in $\mathrm{Fe}(\mathrm{II})-\mathrm{Fe}(\mathrm{III})$ transition zones in a variety of aquatic and terrestrial environments including groundwater [101,102], surface waters [103], soils [104-108], and sediments [109-111], where green rust minerals such as fougérite, trébeurdenite, and mössbauerite [112-114] may play a central role in Fe redox cycling. Green rusts have been reported as secondary mineralization products of the bioreduction of Fe(III) oxides in laboratory-based studies under a wide range of experimental conditions [16,33-35,39,41,44-50,53,55,76,97,100,115-119]. Both carbonate and sulfate green rusts formed depending on the anionic composition of our experimental systems. Carbonate green rust formed in chloride-amended systems, consistent with the affinity of pyroaurite-type layered double hydroxides for carbonate in the interlayer relative to chloride [120]. Furthermore, the production of $\mathrm{Fe}(\mathrm{II})$ is coupled to the formation of carbonate from the oxidation of organic electron donors, allowing for carbonate green rust precipitation. Like carbonate, sulfate is preferred over chloride as an interlayer anion in green rusts; as such sulfate green rust formed in our sulfate-amended systems. However, as carbonate accumulates from the oxidation of the organic electron donors, carbonate green rust forms as carbonate is preferred over sulfate in the interlayer. Only carbonate green rust remained in the formate/sulfate system, however both carbonate and sulfate green rusts remained in the lactate/sulfate, and NAG/sulfate systems, likely due to lower carbonate production in those systems.

Siderite $\left(\mathrm{FeCO}_{3}\right)$ is a geologically significant iron carbonate mineral that is of commercial interest due to its use as a minor iron ore. Siderite is commonly reported as a secondary mineral during the bioreduction of $\mathrm{Fe}(\mathrm{III})$ oxides in systems with substantial carbonate concentrations (i.e., $>20 \mathrm{mM}$ ) $[9,33,36,121-123]$. In our experimental systems, siderite was observed as the sole secondary mineral in pyruvate-and serine-amended systems (note, as discussed above, serine is likely converted to pyruvate by $S$. putrefaciens CN32). Siderite was also the sole secondary mineral formed during the bioreduction of ferrihydrite and akaganeite by Shewanella sp. HN-41 and S. putrefaciens W3-18-1, respectively, with pyruvate as the electron donor [52,53]. Although we were not able to measure carbonate concentrations in our experimental systems, it is likely that the use of pyruvate (and serine) as an electron donor results in production of $>30 \mathrm{mM}$ given the accumulation of $\sim 60 \mathrm{mM} \mathrm{Fe}$ (II) and the 
formation of 1 mole of carbonate per 2 moles of Fe(III) reduced based on the oxidation of pyruvate to acetate and carbon dioxide.

In our experimental systems we typically observed formation of either green rust or siderite, except in the NAG-amended systems, where green rust and a minor amount of siderite $(<30 \%$ of $\mathrm{Fe}(\mathrm{II})$ ) were observed. Geochemical modeling indicates that $\mathrm{pH}$ and carbonate concentration are the key factors determining the prevalence of carbonate green rust verses siderite (Figure 15); ferrous hydroxide and chukanovite were considered in the modeling even though neither were observed in any of our experimental systems. At $a\left[\mathrm{HCO}_{3}{ }^{-}\right]=10^{-6}$, siderite is not stable. With increasing $a\left[\mathrm{HCO}_{3}{ }^{-}\right]$the stability field of siderite increases and the stability fields of carbonate green rust and ferrous hydroxide shift to higher $\mathrm{pH}$. These results are consistent with the observed distribution of carbonate green rusts in systems with electron donors likely to result in lower carbonate concentrations (formate, lactate, and NAG) and siderite in systems likely to produce high carbonate concentrations (pyruvate and serine).
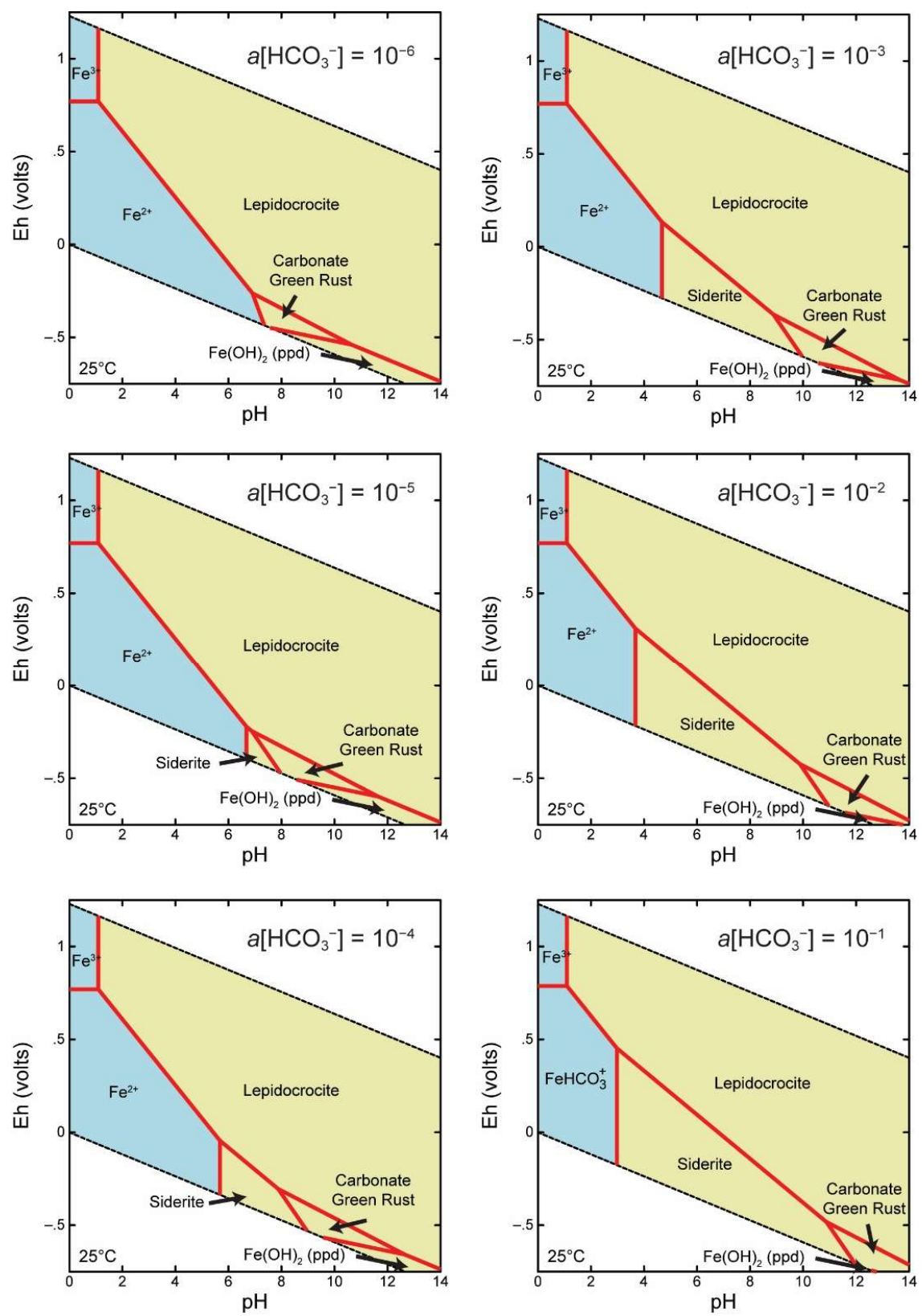

Figure 15. Eh-pH diagrams of iron $\left(a\left[\mathrm{Fe}^{2+}\right]=10^{-3}\right)$ in aqueous solution containing dissolved carbonate ranging from $a\left[\mathrm{HCO}_{3}^{-}\right]=10^{-6}-10^{-1}$ at $30^{\circ} \mathrm{C}$. 


\subsection{Environmental Relevance}

Largely through the activity of DIRB, Fe(II) is typically one of the most abundant reductants present in aquatic and terrestrial environments under suboxic and anoxic conditions [124-126], often providing substantial redox buffering capacity to these systems. Fe(II) is a reductant for a wide range of contaminants, however, the redox reactivity of Fe(II) depends strongly on its speciation [127-131]. Among the Fe(II)-bearing secondary minerals resulting from DIR of Fe(III) oxides, green rusts are a particularly effective reductant for a wide range of contaminants of concern, including chlorinated solvents, nitroaromatics, azo dyes, toxic metals, metallolids, and radionuclides [127,128,132-153]. Therefore, identifying the factors (e.g., availability of specific electron donors) that lead to the formation of green rusts and other reactive $\mathrm{Fe}(\mathrm{II})$ phases in natural and engineered environments may lead to better management of contaminant fate and transport (e.g., in situ biostimulation of DIRB for contaminant bioremediation).

Author Contributions: E.J.O. initiated the concept and carried out the experiments. C.A.G. and M.M.S. performed the ${ }^{57} \mathrm{Fe}$ Mössbauer analysis. T.M.F. performed the geochemical modeling. E.J.O. drafted the manuscript and all authors reviewed and edited the final version.

Funding: This research is part of the Subsurface Science Scientific Focus Area (SFA) at Argonne National Laboratory supported by the Subsurface Biogeochemical Research Program, Office of the Biological and Environmental Research, Office of Science, U.S. Department of Energy (DOE), under contract DE-AC02-06CH11357. This work was performed, in part, at the Center for Nanoscale Materials, a U.S. Department of Energy Office of Science User Facility, and supported by the U.S. Department of Energy, Office of Science, under Contract No. DE-AC02-06CH11357.

Acknowledgments: We thank Russell Cook for his assistance with SEM imaging and two anonymous reviewers for their thoughtful reviews of the manuscript.

Conflicts of Interest: The authors declare no conflict of interest. The funders had no role in the design of the study; in the collection, analyses, or interpretation of data; in the writing of the manuscript, or in the decision to publish the results.

\section{References}

1. Canfield, D.E.; Thamdrup, B.; Hansen, J.W. The anaerobic degradation of organic matter in Danish coastal sediments: Iron reduction, manganese reduction, and sulfate reduction. Geochim. Cosmochim. Acta 1993, 57, 3867-3883. [CrossRef]

2. Nealson, K.H.; Saffarini, D.A. Iron and manganese in anaerobic respiration: Environmental significance, physiology, and regulation. Annu. Rev. Microbiol. 1994, 48, 311-343. [CrossRef] [PubMed]

3. Roden, E.E.; Wetzel, R.G. Organic carbon oxidation and methane production by microbial Fe(III) oxide reduction in vegetated and unvegetated freshwater wetland sediments. Limnol. Oceanogr. 1996, 41, 1733-1748. [CrossRef]

4. Lovley, D.R. Fe(III) and Mn(IV) reduction. In Environmental Microbe-Metal Interactions; Lovley, D.R., Ed.; American Society for Microbiology Press: Washington, DC, USA, 2000; pp. 3-30.

5. Thamdrup, B. Bacterial manganese and iron reduction in aquatic sediments. Adv. Microb. Ecol. 2000, 16, $41-84$.

6. Caccavo, F., Jr.; Coates, J.D.; Rossello-Mora, R.A.; Ludwig, W.; Schleifer, K.H.; Lovley, D.R.; McInerney, M.J. Geovibrio ferrireducens, a phylogenetically distinct dissimilatory Fe(III)-reducing bacterium. Arch. Microbiol. 1996, 165, 370-376. [CrossRef] [PubMed]

7. Coates, J.D.; Bhupathiraju, V.K.; Achenbach, L.; McInerney, M.J.; Lovley, D.R. Geobacter hydrogenophilus, Geobacter chapelli and Geobacter grbiciae, three new, strictly anaerobic, dissimilatory Fe(III)-reducers. Int. J. Syst. Evol. Microbiol. 2001, 51, 581-588. [CrossRef] [PubMed]

8. Coates, J.D.; Ellis, D.J.; Gaw, C.V.; Lovley, D.R. Geothrix fermentans gen. nov., sp. nov., a novel Fe(III)-reducing bacterium from a hydrocarbon-contaminated aquifer. Int. J. Syst. Bacteriol. 1999, 49, 1615-1622. [CrossRef]

9. Dong, Y.; Sanford, R.A.; Boyanov, M.I.; Kemner, K.M.; Flynn, T.M.; O’Loughlin, E.J.; Chang, Y.J.; Locke, R.A., Jr.; Weber, J.R.; Egan, S.M.; et al. Orenia metallireducens sp. nov. strain Z6, a novel metal-reducing member of the phylum firmicutes from the deep subsurface. Appl. Environ. Microbiol. 2016, 82, 6440-6453. [CrossRef] 
10. Dong, Y.; Sanford, R.A.; Boyanov, M.I.; Kemner, K.M.; Flynn, T.M.; O’Loughlin, E.J.; Locke Ii, R.A.; Weber, J.R.; Egan, S.M.; Fouke, B.W. Tepidibacillus decaturensis sp. nov.: A microaerophilic, moderately thermophilic iron-reducing bacterium isolated from a depth of $1.7 \mathrm{~km}$ in the Illinois Basin, USA. Int. J. Syst. Evol. Microbiol. 2016. [CrossRef]

11. Ettwig, K.F.; Zhu, B.; Speth, D.; Keltjens, J.T.; Jetten, M.S.; Kartal, B. Archaea catalyze iron-dependent anaerobic oxidation of methane. Proc. Natl. Acad. Sci. USA 2016. [CrossRef]

12. Kashefi, K.; Lovley, D.R. Reduction of Fe(III), Mn(IV), and toxic metals at $100^{\circ} \mathrm{C}$ by Pyrobacterium islandicum. Appl. Environ. Microbiol. 2000, 66, 1050-1056. [CrossRef] [PubMed]

13. Sanford, R.A.; Cole, J.R.; Tiedje, J.M. Characterization and description of Anaeromyxobacter dehalogens gen. nov., sp. nov., an Aryl-halorespiring facultative anaerobic myxobacterium. Appl. Environ. Microbiol. 2002, 68, 893-900. [CrossRef] [PubMed]

14. Roh, Y.; Liu, S.V.; Li, G.; Huang, H.; Phelps, T.J.; Zhou, J. Isolation and characterization of metal-reducing Thermoanaerobacter strains from deep subsurface environments of the Piceance Basin, Colorado. Appl. Environ. Microbiol. 2002, 68, 6013-6020. [CrossRef] [PubMed]

15. Lovley, D.R.; Giovanoli, S.J.; White, D.C.; Champine, J.E.; Phillips, E.J.P.; Gorby, Y.A.; Goodwin, S. Geobacter metallireducens gen. nov. sp. nov., a microorganism capable of coupling the complete oxidation of organic compounds to the reduction of iron and other metals. Arch. Microbiol. 1993, 159, 336-344. [CrossRef] [PubMed]

16. O'Loughlin, E.J.; Larese-Casanova, P.; Scherer, M.M.; Cook, R.E. Green rust formation from the bioreduction of g-FeOOH (lepidocrocite): Comparison of several Shewanella species. Geomicrobiol. J. 2007, 24, 211-230. [CrossRef]

17. Slobodkin, A.; Reysenbach, A.L.; Strutz, N.; Dreier, M.; Wiegel, J. Thermoterrabacterium ferrireducens gen. nov., sp. nov., a thermophilic anaerobic dissimilatory Fe(III)-reducing bacterium from a continental hot spring. Int. J. Syst. Bacteriol. 1997, 47, 541-547. [CrossRef] [PubMed]

18. Greene, A.C.; Patel, B.K.; Sheehy, A.J. Deferribacter thermophilus gen. nov., sp. nov., a novel thermophilic manganese- and iron-reducing bacterium isolated from a petroleum reservoir. Int. J. Syst. Bacteriol. 1997, 47, 505-509. [CrossRef] [PubMed]

19. Roh, Y.; Chon, C.-M.; Moon, J.-W. Metal reduction and biomineralization by an alkaliphilic metal-reducing bacterium, Alkaliphilus metalliredigens (QYMF). Geosci. J. 2007, 11, 415-423. [CrossRef]

20. Cutting, R.S.; Coker, V.S.; Fellowes, J.W.; Lloyd, J.R.; Vaughan, D.J. Mineralogical and morphological constraints on the reduction of Fe(III) minerals by Geobacter sulfurreducens. Geochim. Cosmochim. Acta 2009, 73, 4004-4022. [CrossRef]

21. Shelobolina, E.S.; Vanpraagh, C.G.; Lovley, D.R. Use of ferric and ferrous iron containing minerals for respiration by Desulfitobacterium frappieri. Geomicrobiol. J. 2003, 20, 143-156. [CrossRef]

22. Kostka, J.E.; Haefele, E.; Viehweger, R.; Stucki, J.W. Respiration and dissolution of iron(III)-containing clay minerals by bacteria. Environ. Sci. Technol. 1999, 33, 3127-3133. [CrossRef]

23. Kostka, J.E.; Nealson, K.H. Dissolution and reduction of magnetite by bacteria. Environ. Sci. Technol. 1995, 29, 2535-2540. [CrossRef] [PubMed]

24. Urrutia, M.M.; Roden, E.E.; Fredrickson, J.K.; Zachara, J.M. Microbial and surface chemistry controls on reduction of synthetic Fe(III) oxide minerals by the dissimilatory iron-reducing bacterium Shewanella alga. Geomicrobiology 1998, 15, 269-291. [CrossRef]

25. Zachara, J.M.; Fredrickson, J.K.; Li, S.-M.; Kennedy, D.W.; Smith, S.C.; Gassman, P.L. Bacterial reduction of crystalline $\mathrm{Fe}^{3+}$ oxides in single phase suspension and subsurface materials. Am. Mineral. 1998, 83, 1426-1443. [CrossRef]

26. Lee, S.H.; Lee, I.; Roh, Y. Biomineralization of a poorly crystalline Fe(III) oxide, akaganeite, by an anaerobic $\mathrm{Fe}(\mathrm{III})$-reducing bacterium (Shewanella alga) isolated from marine environment. Geosci. J. 2003, 7, 217-226. [CrossRef]

27. Seabaugh, J.L.; Dong, H.; Kukkadapu, R.K.; Eberl, D.D.; Morton, J.P.; Kim, J. Microbial reduction of Fe(III) in the Fithian and Muloorina illites: Contrasting extents and rates of bioreduction. Clays Clay Miner. 2006, 54, 67-79. [CrossRef]

28. O'Loughlin, E.J.; Gorski, C.A.; Scherer, M.M. Effects of phosphate on secondary mineral formation during the bioreduction of akaganeite (b-FeOOH): Green rust versus framboidal magnetite. Curr. Inorg. Chem. 2015, 5, 214-224. [CrossRef] 
29. Thurman, E.M. Organic Geochemistry of Natural Waters; Martinus Nijhoff/Dr. W. Junk Publishers: Dordrecht, The Netherlands, 1985; p. 497.

30. Megonigal, J.P.; Hines, M.E.; Visscher, P.T. Anaerobic metabolism: Linkages to trace gasses and aerobic processes. In Biogeochemistry; Schlesinger, W.H., Ed.; Elsevier-Pergamon: Oxford, UK, 2004; pp. 317-424.

31. Lovley, D.R. Microbial Fe(III) reduction in subsurface environments. FEMS Microbiol. Rev. 1997, 20, $305-313$. [CrossRef]

32. Lovley, D.R.; Stolz, J.F.; Nord, G.L., Jr.; Phillips, E.J.P. Anaerobic production of magnetite by a dissimilatory iron-reducing microorganism. Nature 1987, 330, 252-254. [CrossRef]

33. Fredrickson, J.K.; Zachara, J.M.; Kennedy, D.W.; Dong, H.; Onstott, T.C.; Hinman, N.W.; Li, S.-M. Biogenic iron mineralization accompanying the dissimilatory reduction of hydrous ferric oxide by a groundwater bacterium. Geochim. Cosmochim. Acta 1998, 62, 3239-3257. [CrossRef]

34. Ona-Nguema, G.; Abdelmoula, M.; Jorand, F.; Benali, O.; Géhin, A.; Block, J.-C.; Génin, J.-M.R. Iron(II,III) hydroxycarbonate green rust formation and stabilization from lepidocrocite bioreduction. Environ. Sci. Technol. 2002, 36, 16-20. [CrossRef] [PubMed]

35. Glasauer, S.; Weidler, P.G.; Langley, S.; Beveridge, T.J. Controls on Fe reduction and mineral formation by a subsurface bacterium. Geochim. Cosmochim. Acta 2003, 67, 1277-1288. [CrossRef]

36. Roh, Y.; Zhang, C.-L.; Vali, H.; Lauf, R.J.; Zhou, J.; Phelps, T.J. Biogeochemical and environmental factors in Fe biomineralization: Magnetite and siderite formation. Clays Clay Miner. 2003, 51, 83-95. [CrossRef]

37. Kukkadapu, R.K.; Zachara, J.M.; Fredrickson, J.K.; Kennedy, D.W.; Dohnalkova, A.C.; Mccready, D.E. Ferrous hydroxy carbonate is a stable transformation product of biogenic magnetite. Am. Mineral. 2005, 90, 510-515. [CrossRef]

38. Behrends, T.; Van Cappellen, P. Transformation of hematite into magnetite during dissimilatory iron reduction-conditions and mechanisms. Geomicrobiol. J. 2007, 24, 403-416. [CrossRef]

39. Boyanov, M.I.; O'Loughlin, E.J.; Kemner, K.M. Iron phase transformations resulting from the respiration of Shewanella putrefaciens on a mixed mineral phase. J. Phys. Conf. Ser. 2009, 190, 012193. [CrossRef]

40. Shelobolina, E.; Konishi, H.; Xu, H.; Benzine, J.; Xiong, M.Y.; Wu, T.; Blothe, M.; Roden, E. Isolation of phyllosilicate-iron redox cycling microorganisms from an illite-smectite rich hydromorphic soil. Front. Microbiol. 2012, 3, 134. [CrossRef]

41. Zegeye, A.; Mustin, C.; Jorand, F. Bacterial and iron oxide aggregates mediate secondary iron mineral formation: Green rust versus magnetite. Geobiology 2010, 8, 209-222. [CrossRef]

42. Zachara, J.M.; Kukkadapu, R.K.; Frederickson, J.K.; Gorby, Y.A.; Smith, S.C. Biomineralization of poorly crystalline Fe(III) oxides by dissimilatory metal reducing bacteria (DMRB). Geomicrobiol. J. 2002, 19, 179-207. [CrossRef]

43. Bae, S.; Lee, W. Biotransformation of lepidocrocite in the presence of quinones and flavins. Geochim. Cosmochim. Acta 2013, 10. [CrossRef]

44. O'Loughlin, E.J.; Gorski, C.; Scherer, M.M.; Boyanov, M.I.; Kemner, K.M. Effects of oxyanions, natural organic matter, and cell density on the bioreduction of lepidocrocite ( $\mathrm{g}-\mathrm{FeOOH})$ and secondary mineral formation. Environ. Sci. Technol. 2010, 44, 4570-4576. [CrossRef] [PubMed]

45. Zegeye, A.; Ruby, C.; Jorand, F. Kinetic and thermodynamic analysis during dissimilatory g-FeOOH reduction: Formation of green rust 1 and magnetite. Geomicrobiol. J. 2007, 24, 51-64. [CrossRef]

46. Salas, E.C.; Berelson, W.M.; Hammond, D.E.; Kampf, A.R.; Nealson, K.H. The impact of bacterial strain on the products of dissimilatory iron reduction. Geochim. Cosmochim. Acta 2010, 74, 574-583. [CrossRef] [PubMed]

47. Borch, T.; Masue, Y.; Kukkadapu, R.K.; Fendorf, S. Phosphate imposed limitations on biological reduction and alteration of ferrihydrite. Environ. Sci. Technol. 2007, 41, 166-172. [CrossRef] [PubMed]

48. Kukkadapu, R.K.; Zachara, J.M.; Fredrickson, J.K.; Kennedy, D.W. Biotransformation of two-line silica-ferrihydrite by a dissimilatory $\mathrm{Fe}(\mathrm{III})$-reducing bacterium: Formation of carbonate green rust in the presence of phosphate. Geochim. Cosmochim. Acta 2004, 68, 2799-2814. [CrossRef]

49. Sergent, A.-S.; Jorand, F.; Hanna, K. Effects of Si-bearing minerals on the nature of secondary iron mineral products from lepidocrocite bioreduction. Chem. Geol. 2011, 289, 86-97. [CrossRef]

50. Jorand, F.; Zegeye, A.; Ghanbaja, J.; Abdelmoula, M. The formation of green rust induced by tropical river biofilm components. Sci. Total Envrion. 2011, 409, 2586-2596. [CrossRef]

51. Fredrickson, J.K.; Kota, S.; Kukkadapu, R.K.; Liu, C.; Zachara, J.M. Influence of electron donor/acceptor concentrations on hydrous ferric oxide (HFO) bioreduction. Biodegradation 2003, 14, 91-103. [CrossRef] 
52. Lee, J.-H.; Roh, Y.; Kim, K.-W.; Hur, H.-G. Organic acid-dependent iron mineral formation by a newly isolated iron-reducing bacterium, Shewanella sp. HN-41. Geomicrobiol. J. 2007, 24, 31-41. [CrossRef]

53. Salas, E.C.; Berelson, W.M.; Hammond, D.E.; Kampf, A.R.; Nealson, K.H. The influence of carbon source on the products of dissimilatory iron reduction. Geomicrobiol. J. 2009, 26, 451-462. [CrossRef]

54. Lovley, D. Dissimilatory Fe(III)- and Mn(IV)-reducing prokaryotes. In The Prokaryotes_Prokaryotic Physiology and Biochemistry; Dworkin, M., Ed.; Springer: Berlin/Heidelburg, Germany, 2013; pp. 287-308.

55. O'Loughlin, E.J. Effects of electron transfer mediators on the biodegradation of lepidocrocite $(\mathrm{g}-\mathrm{FeOOH})$ by Shewanella putrefaciens CN32. Environ. Sci. Technol. 2008, 42, 6876-6882. [CrossRef] [PubMed]

56. Stookey, L.L. Ferrozine-A new spectrophotometric reagent for iron. Anal. Chem. 1970, 42, 779-781. [CrossRef]

57. Sørensen, J. Reduction of ferric iron in anaerobic, marine sediment and interaction with reduction of nitrate and sulfate. Appl. Environ. Microbiol. 1982, 43, 319-324. [PubMed]

58. Bethke, C.M. Geochemical and Biogeochemical Reaction Modelling, 2nd ed.; Cambridge University Press: Cambridge, UK, 2008; p. 543.

59. Delany, J.M.; Lundeen, S.R. The LLNL Thermochemical Database; Lawrence Livermore National Laboratory: Livermore, CA, USA, 1989; Report UCRL-21658; p. 150.

60. Allison, J.D.; Brown, D.S.; Novo-Gradac, K.J. MINTEQA2/PRODEFA2, A Geochemical Assessment Model for Environmental Systems: Version 3.0 User's Manual; USEPA: Washington, DC, USA, 1991.

61. Drissi, S.H.; Refait, P.; Abdelmoula, M.; Génin, J.M.R. The preparation and thermodynamic properties of $\mathrm{Fe}(\mathrm{II})-\mathrm{Fe}(\mathrm{III})$ hydroxide-carbonate (green rust 1); Pourbaix diagram of iron in carbonate-containing aqueous media. Corros. Sci. 1995, 37, 2025-2041. [CrossRef]

62. Azoulay, I.; Rémazeilles, C.; Refait, P. Determination of standard Gibbs free energy of formation of chukanovite and Pourbaix diagrams of iron in carbonated media. Corros. Sci. 2012, 58, 229-236. [CrossRef]

63. O’Loughlin, E.J.; Boyanov, M.I.; Flynn, T.M.; Gorski, C.; Hofmann, S.M.; McCormick, M.L.; Scherer, M.M.; Kemner, K.M. Effects of bound phosphate on the bioreduction of lepidocrocite ( $\mathrm{g}-\mathrm{FeOOH})$ and maghemite (g- $\mathrm{Fe}_{2} \mathrm{O}_{3}$ ) and formation of secondary minerals. Environ. Sci. Technol. 2013, 47, 9157-9166. [CrossRef]

64. Hau, H.H.; Gralnick, J.A. Ecology and biotechnology of the genus Shewanella. Annu. Rev. Microbiol. 2007, 61, 237-258. [CrossRef] [PubMed]

65. Fredrickson, J.K.; Romine, M.F.; Beliaev, A.S.; Auchtung, J.M.; Driscoll, M.E.; Gardner, T.S.; Nealson, K.H.; Osterman, A.L.; Pinchuk, G.; Reed, J.L.; et al. Towards environmental systems biology of Shewanella. Nat. Rev. Microbiol. 2008, 6, 592-603. [CrossRef] [PubMed]

66. Janda, J.M.; Abbott, S.L. The genus Shewanella: From the briny depths below to human pathogen. Crit. Rev. Microbiol. 2014, 40, 293-312. [CrossRef]

67. Serres, M.H.; Riley, M. Genomic analysis of carbon source metabolism of Shewanella oneidensis MR-1: Predictions versus experiments. J. Bacteriol. 2006, 188, 4601-4609. [CrossRef]

68. Pinchuk, G.; Hill, E.A.; Geydebrekht, O.V.; De Ingeniis, J.; Zhang, X.; Osterman, A.; Scott, J.H.; Reed, S.B.; Romine, M.F.; Konopka, A.E.; et al. Constraint-based model of Shewanella oneidensis MR-1 metabolism: A tool for data analysis and hypothesis generation. PLoS Comput. Biol. 2010, 6, e1000822. [CrossRef] [PubMed]

69. Rodionov, D.A.; Yang, C.; Li, X.; Rodionova, I.A.; Wang, Y.; Obraztsova, A.Y.; Zagnitko, O.P.; Overbeek, R.; Romine, M.F.; Reed, S.; et al. Genomic encyclopedia of sugar utilization pathways in the Shewanella genus. BMC Genom. 2010, 11, 494. [CrossRef]

70. Nealson, K.H.; Scott, J. Ecophysiology of the genus Shewanella. In The Prokaryotes: An Evolving Electronic Resource for the Microbiological Community; Dworkin, M., Ed.; Springer: New York, NY, USA, 2006; Volume 6, pp. 848-860.

71. Caccavo, F., Jr.; Blakemore, R.P.; Lovley, D.R. A hydrogen-oxidizing, Fe(III)-reducing microorganism from the Great Bay Estuary, New Hampshire. Appl. Environ. Microbiol. 1992, 58, 3211-3216. [PubMed]

72. Lovley, D.R.; Phillips, E.J.P.; Lonergan, D.J. Hydrogen and formate oxidation coupled to dissimilatory reduction of iron or manganese by Alteromonas putrefaciens. Appl. Environ. Microbiol. 1989, 55, 700-706. [PubMed]

73. Liu, C.; Gorby, Y.A.; Zachara, J.M.; Fredrickson, J.K.; Brown, C.F. Reduction kinetics of Fe(III), Co(III), U(VI), $\mathrm{Cr}(\mathrm{VI})$, and $\mathrm{Tc}(\mathrm{VII})$ in cultures of dissimilatory metal-reducing bacteria. Biotechnol. Bioeng. 2002, 80, 637-649. [CrossRef] [PubMed] 
74. Stapleton, R.D.; Sabree, Z.L.; Palumbo, A.V.; Moyer, C.L.; Devol, A.H.; Roh, Y.; Zhou, J. Metal reduction at cold temperatures by Shewanella isolates from various marine environments. Aquat. Microb. Ecol. 2005, 38, 81-91. [CrossRef]

75. Roh, Y.; Gao, H.; Vali, H.; Kennedy, D.W.; Yang, Z.K.; Gao, W.; Dohnalkova, A.C.; Stapleton, R.D.; Moon, J.-W.; Phelps, T.J.; et al. Metal reduction and iron biomineralization by a psychrotolerant Fe(III)-reducing bacterium, Shewanella sp. strain PV-4. Appl. Environ. Microbiol. 2006, 72, 3236-3244. [CrossRef]

76. Zegeye, A.; Ona-Nguema, G.; Carteret, C.; Huguet, L.; Abdelmoula, M.; Jorand, F. Formation of hydroxysulfate green rust 2 as a single iron(II-III) mineral in microbial culture. Geomicrobiol. J. 2005, 22, 389-399. [CrossRef]

77. Jorand, F.P.A.; Sergent, A.S.; Remy, P.P.; Bihannic, I.; Ghanbaja, J.; Lartiges, B.; Hanna, K.; Zegeye, A. Contribution of anionic vs. neutral polymers to the formation of green rust 1 from $\gamma$-FeOOH bioreduction. Geomicrobiol. J. 2013, 30, 600-615. [CrossRef]

78. Pinchuk, G.E.; Geydebrekht, O.V.; Hill, E.A.; Reed, J.L.; Konopka, A.E.; Beliaev, A.S.; Fredrickson, J.K. Pyruvate and lactate metabolism by Shewanella oneidensis MR-1 under fermentation, oxygen limitation, and fumarate respiration conditions. Appl. Environ. Microbiol. 2011, 77, 8234-8240. [CrossRef]

79. Toffin, L.; Bidault, A.; Pignet, P.; Tindall, B.J.; Slobodkin, A.; Kato, C.; Prieur, D. Shewanella profunda sp. nov., isolated from deep marine sediment of the Nanki Trough. Int. J. Syst. Evol. Microbiol. 2004, 54, 1943-1949. [CrossRef] [PubMed]

80. Ringø, E.; Stenberg, E.; Strøm, A.R. Amino acid and lactate catabolism in trimethylamine oxide respiration of Alteromonas putrefaciens NCMB 1735. Appl. Environ. Microbiol. 1984, 46, 1084-1089.

81. Jørgensen, N.O.G.; Stepanaukas, R.; Pedersen, A.-G.U.; Hansen, M.; Nybroe, O. Occurrence and degradation of peptidoglycan in aquatic environments. FEMS Microbiol. Ecol. 2003, 46, 269-280. [CrossRef]

82. Beier, S.; Bertilsson, S. Bacterial chitin degradation-mechanisms and ecophysiological strategies. Front. Microbiol. 2013, 4, 149. [CrossRef] [PubMed]

83. Nedoma, J.; Vrba, J.; Hejzlar, J.; Šimek, K.; Straškrabová, V. N-acetylglucosamine dynamics in freshwater environments: Concentration of amino sugars, extracellular enzyme activities, and microbial uptake. Limnol. Oceanogr. 1994, 39, 1088-1100. [CrossRef]

84. Riemann, L.; Azam, F. Widespread N-acetyl-D-glucosamine uptake among pelagic marine bacteria and its ecological implications. Appl. Environ. Microbiol. 2002, 68, 5554-5562. [CrossRef] [PubMed]

85. Roberts, P.; Jones, D.L. Microbial and plant uptake of free amino sugars in grassland soils. Soil Biol. Biochem. 2012, 49, 139-149. [CrossRef]

86. Beier, S.; Bertilsson, S. Uncoupling of chitinase activity and uptake of hydrolysis products in freshwater bacterioplankton. Limnol. Oceanogr. 2011, 56, 1179-1188. [CrossRef]

87. Tada, Y.; Grossart, H.P. Community shifts of actively growing lake bacteria after N-acetyl-glucosamine addition: Improving the BrdU-FACS method. ISME J. 2014, 8, 441-454. [CrossRef]

88. Satomi, M.; Oikawa, H.; Yano, Y. Shewanella marinintestina sp. nov., Shewanella schlegeliana sp. nov. and Shewanella sairae sp. nov., novel eicosapentaenoic-acid-producing marine bacteria isolated from sea-animal intestines. Int. J. Syst. Evol. Microbiol. 2003, 53, 491-499. [CrossRef]

89. Yang, C.; Rodionov, D.A.; Li, X.; Laikova, O.N.; Gelfand, M.S.; Zagnitko, O.P.; Romine, M.F.; Obraztsova, A.Y.; Nealson, K.H.; Osterman, A.L. Comparative genomics and experimental characterization of $\mathrm{N}$-acetylglucosamine utilization pathway of Shewanella oneidensis. J. Biol. Chem. 2006, 281, 29872-29885. [CrossRef] [PubMed]

90. Bowman, J.P.; McCammon, S.; Nichols, D.S.; Skerratt, J.H.; Rea, S.M.; Nichols, P.D.; McMeekin, T.A. Shewanella gelidimarina sp. nov. and Shewanella frigidimarina sp. nov., novel antarctic species with the ability to produce eicosapentaenoic acid (20:5 w3) and grow anaerobically by dissimilatory Fe(III) reduction. Int. J. Syst. Bacteriol. 1997, 47, 1040-1047. [CrossRef] [PubMed]

91. Bozal, N.; Montes, M.J.; Tudela, E.; Jimenez, F.; Guinea, J. Shewanella frigidimarina and Shewanella livingstonensis sp. nov. isolated from Antarctic coastal areas. Int. J. Syst. Evol. Microbiol. 2002, 52, 195-205. [CrossRef] [PubMed]

92. Zavarzina, D.G.; Sokolova, T.G.; Tourova, T.P.; Chernyh, N.A.; Kostrikina, N.A.; Bonch-Osmolovskaya, E.A. Thermincola ferriacetica sp. nov., a new anaerobic, thermophilic, facultatively chemolithoautotrophic bacterium capable of dissimilatory Fe(III) reduction. Extremeophiles 2007, 11, 1-7. [CrossRef] [PubMed] 
93. Akob, D.M.; Mills, H.J.; Gihring, T.M.; Kerkhof, L.; Stucki, J.W.; Anastacio, A.S.; Chin, K.-J.; Kusel, K.; Palumbo, A.V.; Watson, D.B.; et al. Functional diversity and electron donor dependence of microbial populations capable of $\mathrm{U}(\mathrm{VI})$ reduction in radionuclide-contaminated subsurface sediments. Appl. Environ. Microbiol. 2008, 74, 3159-3170. [CrossRef]

94. Lentini, C.J.; Wankel, S.D.; Hansel, C.M. Enriched iron(III)-reducing bacterial communities are shaped by carbon substrate and iron mineralogy. Front. Microbiol. 2012, 3. [CrossRef] [PubMed]

95. Petrie, L.; North, N.N.; Dollhopf, S.L.; Balkwill, D.L.; Kostka, J.E. Enumeration and characterization of iron(III)-reducing microbial communities and acidic subsurface sediments contaminated with uranium(VI). Appl. Environ. Microbiol. 2003, 69, 7467-7479. [CrossRef]

96. Kwon, M.J.; O’Loughlin, E.J.; Boyanov, M.I.; Brulc, J.M.; Johnston, E.R.; Kemner, K.M.; Antonopoulos, D.A. Impact of organic carbon electron donors on microbial community development under iron- and sulfate-reducing conditions. PLoS ONE 2016, 11, 1-22. [CrossRef]

97. Jung, J.; Bae, S.; Lee, W. Indirect contact of bio-transformation of lepidocrocite: Role of electron transfer mediator. Sustain. Environ. Res. 2012, 23, 193-198.

98. Ona-Nguema, G.; Jorand, F.; Benali, O.; Abdelmoula, M.; Génin, J.-M.R.; Block, J.-C. Key role of the kinetics of g-FeOOH bioreduction on the formation of Fe(II-III) minerals. In Hyperfine Interactions (C), Proceedings of the International Conference on the Applications of the Mössbauer Effect (ICAME 2001), Oxford, UK, 2-7 September 2001; Thomas, M.F., Williams, J.M., Gibb, T.C., Eds.; Kluwer Academic Publishers: Dordrecht, The Netherlands, 2002; pp. 415-418.

99. Ona-Nguema, G.; Morin, G.; Juillot, F.; Calas, G.; Brown, G.E., Jr. EXAFS analysis of arsenite adsorption onto two-line ferrihydrite, hematite, goethite, and lepidocrocite. Environ. Sci. Technol. 2005, 39, 9147-9155. [CrossRef]

100. Ona-Nguema, G.; Morin, G.; Wang, Y.; Menguy, N.; Juillot, F.; Olovi, L.; Aquilanti, G.; Abdelmoula, M.; Ruby, C.; Bargar, J.R.; et al. Arsenite sequestration at the surface of nano- $\mathrm{Fe}(\mathrm{OH})_{2}$, ferrous-carbonate hydroxide, and green-rust after bioreduction of arsenic-sorbed lepidocrocite by Shewanella putrefaciens. Geochim. Cosmochim. Acta 2009, 73, 1359-1381. [CrossRef]

101. Christiansen, B.C.; Balic-Zunic, T.; Dideriksen, K.; Stipp, S.L.S. Identification of green rust in groundwater. Environ. Sci. Technol. 2009, 43, 3436-3441. [CrossRef] [PubMed]

102. Johnson, C.A.; Freyer, G.; Fabisch, M.; Caraballo, M.A.; Küsel, K.; Hochella, M.F. Observations and assessment of iron oxide and green rust nanoparticles in metal-polluted mine drainage within a steep redox gradient. Environ. Chem. 2014, 11, 377. [CrossRef]

103. Zegeye, A.; Bonneville, S.; Benning, L.G.; Sturm, A.; Fowle, D.A.; Jones, C.; Canfield, D.E.; Ruby, C.; MacLean, L.C.; Nomosatryo, S.; et al. Green rust formation controls nutrient availability in a ferruginous water column. Geology 2012, 40, 599-602. [CrossRef]

104. Feder, F.; Trolard, F.; Klingelhöfer, G.; Bourrié, G. In situ Mössbauer spectroscopy: Evidence for green rust (fougerite) in a gleysol and its mineralogical transformations with time and depth. Geochim. Cosmochim. Acta 2005, 69, 4463-4483. [CrossRef]

105. Génin, J.-M.R.; Bourrié, G.; Trolard, F.; Abdelmoula, M.; Jaffrezic, A.; Refait, P.; Maitre, V.; Humbert, B.; Herbillon, A. Thermodynamic equilibria in aqueous suspensions of synthetic and natural Fe(II)-Fe(III) green rusts: Occurrences of the mineral in hydromorphic soils. Environ. Sci. Technol. 1998, 32, 1058-1068. [CrossRef]

106. Refait, P.; Abdelmoula, M.; Trolard, F.; Génin, J.-M.R.; Ehrhardt, J.J.; Bourrié, G. Mössbauer and XAS study of a green rust mineral: The partial substitution of $\mathrm{Fe}^{2+} \mathrm{by}^{2+} \mathrm{Mg}^{2+}$. Am. Mineral. 2001, 86, 731-739. [CrossRef]

107. Trolard, F.; Génin, J.-M.R.; Abdelmoula, M.; Bourrié, G.; Humbert, B.; Herbillon, A. Identification of a green rust mineral in a reductomorphic soil by Mössbauer and Raman spectroscopies. Geochim. Cosmochim. Acta 1997, 61, 1107-1111. [CrossRef]

108. Weatherington-Rice, J.; Bigham, J.M. Buried pre-Illinoian-age lacustrine deposits with "green rust" colors in Clermont County, Ohio. Ohio J. Sci. 2006, 106, 35-44.

109. Bearcock, J.M.; Perkins, W.T.; Dinelli, E.; Wade, S.C. Fe(II)/Fe(III) "green rust" developed within ocherous coal mine drainage sediment in South Wales, UK. Mineral. Mag. 2006, 70, 731-741. [CrossRef]

110. Bender Koch, C.; Mørup, S. Identification of green rust in an ochre sludge. Clay Miner. 1991, 26, 577-582. [CrossRef] 
111. Root, R.A.; Dixit, S.; Campbell, K.M.; Jew, A.D.; Hering, J.G.; O’Day, P.A. Arsenic sequestration by sorption processes in high-iron sediments. Geochim. Cosmochim. Acta 2007, 71, 5782-5803. [CrossRef]

112. Trolard, F.; Bourrié, G.; Abdelmoula, M.; Refait, P.; Feder, F. Fougerite, a new mineral of the pyroaurite-iowaite group: Description and crystal structure. Clays Clay Miner. 2007, 55, 323-334. [CrossRef]

113. Mills, S.J.; Christy, A.G.; Génin, J.M.R.; Kameda, T.; Colombo, F. Nomenclature of the hydrotalcite supergroup: Natural layered double hydroxides. Mineral. Mag. 2012, 76, 1289-1336. [CrossRef]

114. Génin, J.M.R.; Mills, S.J.; Christy, A.G.; Guérin, O.; Herbillon, A.J.; Kuzmann, E.; Ona-Nguema, G.; Ruby, C.; Upadhyay, C. Mössbauerite, $\mathrm{Fe}_{6}{ }^{3+} \mathrm{O}_{4}(\mathrm{OH})_{8}\left[\mathrm{CO}_{3}\right] \cdot 3 \mathrm{H}_{2} \mathrm{O}$, the fully oxidized 'green rust' mineral from Mont Saint-Michel Bay, France. Mineral. Mag. 2014, 78, 447-465. [CrossRef]

115. Parmar, N.; Gorby, Y.A.; Beveridge, T.J.; Ferris, F.G. Formation of green rust and immobilization of nickel in response to bacterial reduction of hydrous ferric oxide. Geomicrobiol. J. 2001, 18, 375-385. [CrossRef]

116. Jorand, F.; Zegeye, A.; Landry, F.; Ruby, C. Reduction of ferric green rust by Shewanella putrefaciens. Lett. Appl. Microbiol. 2007, 45, 515-521. [CrossRef]

117. Hansel, C.M.; Benner, S.G.; Neiss, J.; Dohnalkova, A.; Kukkadapu, R.K.; Fendorf, S. Secondary mineralization pathways induced by dissimilatory iron reduction of ferrihydrite under advective flow. Geochim. Cosmochim. Acta 2003, 67, 2977-2992. [CrossRef]

118. Borch, T.; Fendorf, S. Phosphate interactions with iron (hydr)oxides: Mineralization pathways and phosphorous retention upon bioreduction. In Adsorption of Metals by Geomedia II Variables, Mechanisms, and Model Applications; Barnett, M.O., Kent, D., Eds.; Elsevier: New York, NY, USA, 2008; Volume 7, pp. 321-348.

119. Etique, M.; Jorand, F.P.; Ruby, C. Magnetite as a precursor for green rust through the hydrogenotrophic activity of the iron-reducing bacteria Shewanella putrefaciens. Geobiology 2016, 14, 237-254. [CrossRef]

120. Refait, P.; Drissi, S.H.; Pytkiewicz, J.; Génin, J.-M.R. The anionic species competition in iron aqueous corrosion: Role of various green rust compounds. Corros. Sci. 1997, 39, 1699-1710. [CrossRef]

121. Dong, H.; Fredrickson, J.K.; Kennedy, D.W.; Zachara, J.M.; Kukkadapu, R.K.; Onstott, T.C. Mineral transformation associated with the microbial reduction of magnetite. Chem. Geol. 2000, 169, 299-318. [CrossRef]

122. Liu, C.; Kota, S.; Zachara, J.M.; Fredrickson, J.K.; Brinkman, C.K. Kinetic analysis of the bacterial reduction of goethite. Environ. Sci. Technol. 2001, 35, 2482-2490. [CrossRef] [PubMed]

123. Lovley, D.R.; Roden, E.E.; Phillips, E.J.P.; Woodward, J.C. Enzymatic iron and uranium reduction by sulfate-reducing bacteria. Mar. Geol. 1993, 113, 41-53. [CrossRef]

124. Hering, J.G.; Stumm, W. Oxidative and reductive dissolution of minerals. In Mineral-Water Interface Geochemistry; Hochella, M.F.J., White, A.F., Eds.; American Mineralogical Society: Washington, DC, USA, 1990; Volume 23, pp. 427-465.

125. Heron, G.; Christensen, T.H. Impact of sediment-bound iron on redox buffering in a landfill leachate polluted aquifer (Vejen, Denmark). Environ. Sci. Technol. 1995, 29, 187-192. [CrossRef] [PubMed]

126. Rügge, K.; Hofstetter, T.B.; Haderlein, S.B.; Bjerg, P.L.; Knudsen, S.; Zraunig, C.; Mosbæk, H.; Christensen, T.H. Characterization of predominant reductants in an anaerobic leachate-contaminated aquifer by nitroaromatic probe compounds. Environ. Sci. Technol. 1998, 32, 23-31. [CrossRef]

127. Elsner, M.; Schwarzenbach, R.P.; Haderlein, S.B. Reactivity of Fe(II)-bearing minerals toward reductive transformation of organic contaminants. Environ. Sci. Technol. 2004, 38, 799-807. [CrossRef] [PubMed]

128. Lee, W.; Batchelor, B. Reductive capacity of natural reductants. Environ. Sci. Technol. 2003, 37, 535-541. [CrossRef]

129. Scheinost, A.C.; Charlet, L. Selenite reduction by mackinawite, magnetite and siderite: XAS characterization of nanosized redox products. Environ. Sci. Technol. 2008, 42, 1984-1989. [CrossRef]

130. Scheinost, A.C.; Kirsch, R.; Banerjee, D.; Fernandez-Martinez, A.; Zaenker, H.; Funke, H.; Charlet, L. X-ray absorption and photoelectron spectroscopy investigation of selenite reduction by $\mathrm{Fe}^{\mathrm{II}}$-bearing minerals. J. Contam. Hydrol. 2008, 102, 228-245. [CrossRef]

131. O'Loughlin, E.J.; Kelly, S.D.; Kemner, K.M. XAFS investigation of the interactions of $\mathrm{U}^{\mathrm{VI}}$ with secondary mineralization products from the bioreduction of Fe ${ }^{\mathrm{III}}$ oxides. Environ. Sci. Technol. 2010, 44, 1656-1661. [CrossRef]

132. Bond, D.L.; Fendorf, S. Kinetics and structural constraints of chromate reduction by green rusts. Environ. Sci. Technol. 2003, 37, 2750-2757. [CrossRef] 
133. Christiansen, B.C.; Geckeis, H.; Marquardt, C.M.; Bauer, A.; Römer, J.; Wiss, T.; Schild, D.; Stipp, S.L.S. Neptunyl $\left(\mathrm{NpO}_{2}{ }^{+}\right)$interaction with green rust, $\mathrm{GR}_{\mathrm{Na}, \mathrm{SO} 4}$. Geochim. Cosmochim. Acta 2011, 75, 1216-1226. [CrossRef]

134. Erbs, M.; Hansen, H.C.B.; Olsen, C.E. Reductive dechlorination of carbon tetrachloride using iron(II) iron(III) hydroxide sulfate (green rust). Environ. Sci. Technol. 1999, 33, 307-311. [CrossRef]

135. Hansen, H.C.B.; Bender Koch, C.; Nancke-Krogh, H.; Borggaard, O.K.; Sorensen, J. Abiotic nitrate reduction to ammonium: Key role of green rust. Environ. Sci. Technol. 1996, 30, 2053-2056. [CrossRef]

136. Hansen, H.C.B.; Guldberg, S.; Erbs, M.; Bender Koch, C. Kinetics of nitrate reduction by green rusts-Effects of interlayer anion and Fe(II):Fe(III) ratio. Appl. Clay Sci. 2001, 18, 81-91. [CrossRef]

137. Heasman, D.M.; Sherman, D.M.; Ragnarsdottir, K.V. The reduction of aqueous $\mathrm{Au}^{3+}$ by sulfide minerals and green rust phases. Am. Mineral. 2003, 88, 725-738. [CrossRef]

138. Kone, T.; Hanna, K.; Abdelmoula, M.; Ruby, C.; Carteret, C. Reductive transformation and mineralization of an azo dye by hydroxysulphate green rust preceding oxidation using $\mathrm{H}_{2} \mathrm{O}_{2}$ at neutral $\mathrm{pH}$. Chemoshpere 2009, 75, 212-219. [CrossRef] [PubMed]

139. Larese-Casanova, P.; Scherer, M.M. Abiotic transformation of hexahydro-1,3,5-trinitro-1,3,5-triazine (RDX) by green rusts. Environ. Sci. Technol. 2008, 42, 3975-3981. [CrossRef]

140. Lee, W.; Batchelor, B. Abiotic reductive dechlorination of chlorinated ethylenes by iron-bearing soil minerals. 2. Green rust. Environ. Sci. Technol. 2002, 36, 5348-5354. [CrossRef]

141. Legrand, L.; El Figuigui, A.; Mercier, F.; Chausse, A. Reduction of aqueous chromate by Fe(II)/Fe(III) carbonate green rust: Kinetic and mechanistic studies. Environ. Sci. Technol. 2004, 38, 4587-4595. [CrossRef]

142. Loyaux-Lawniczak, S.; Refait, P.; Lecomte, P.; Ehrhardt, J.-J.; Génin, J.-M.R. The reduction of chromate ions by Fe(II) layered hydroxides. Hydrol. Earth Syst. Sci. 1999, 3, 593-599. [CrossRef]

143. Mitsunobu, S.; Takahashi, Y.; Sakai, Y. Abiotic reduction of antimony(V) by green rust $\left(\mathrm{Fe}_{4}(\mathrm{II}) \mathrm{Fe}_{2}(\mathrm{III})(\mathrm{OH})_{12} \mathrm{SO}_{4} \cdot 3 \mathrm{H}_{2} \mathrm{O}\right)$. Chemosphere 2008, 70, 942-947. [CrossRef] [PubMed]

144. Myneni, S.C.B.; Tokunaga, T.K.; Brown, G.E., Jr. Abiotic selenium redox transformations in the presence of Fe(II,III) oxides. Science 1997, 278, 1106-1109. [CrossRef]

145. O'Loughlin, E.J.; Burris, D.R. Reduction of halogenated ethanes by green rust. Environ. Toxicol. Chem. 2004, 23, 41-48. [CrossRef]

146. O’Loughlin, E.J.; Kelly, S.D.; Csencsits, R.; Cook, R.E.; Kemner, K.M. Reduction of uranium(VI) by mixed iron(II)/iron(III) hydroxide (green rust): Formation of $\mathrm{UO}_{2}$ nanoparticles. Environ. Sci. Technol. 2003, 37, 721-727. [CrossRef] [PubMed]

147. O'Loughlin, E.J.; Kelly, S.D.; Kemner, K.M.; Csencsits, R.; Cook, R.E. Reduction of Ag ${ }^{\mathrm{I}}, \mathrm{Au}^{\mathrm{III}}, \mathrm{Cu}^{\mathrm{II}}$, and $\mathrm{Hg}^{\mathrm{II}}$ by $\mathrm{Fe}^{\mathrm{II}} / \mathrm{Fe}^{\mathrm{III}}$ hydroxysulfate green rust. Chemoshpere 2003, 53, 437-446. [CrossRef]

148. Pepper, S.E.; Bunker, D.J.; Bryan, N.D.; Livens, F.R.; Charnock, J.M.; Pattrick, R.A.D.; Collison, D. Treatment of radioactive wastes: An X-ray adsorption spectroscopy study of the treatment of technetium with green rust. J. Colloid Interface Sci. 2003, 268, 408-412. [CrossRef]

149. Refait, P.; Simon, L.; Génin, J.-M.R. Reduction of $\mathrm{SeO}_{4}{ }^{2-}$ anions and anoxic formation of iron(II)-iron(III) hydroxy-selenate green rust. Environ. Sci. Technol. 2000, 34, 819-825. [CrossRef]

150. Skovbjerg, L.L.; Stipp, S.L.S.; Utsunomiya, S.; Ewing, R.C. The mechanisms of reduction of hexavalent chromium by green rust sodium sulphate: Formation of Cr-goethite. Geochim. Cosmochim. Acta 2006, 70, 3582-3592. [CrossRef]

151. Williams, A.G.B.; Scherer, M.M. Kinetics of Cr(VI) reduction by carbonate green rust. Environ. Sci. Technol. 2001, 35, 3488-3494. [CrossRef]

152. Yan, S.; Boyanov, M.I.; Mishra, B.; Kemner, K.M.; O’Loughlin, E.J. U(VI) reduction by biogenic and abiotic hydroxycarbonate green rusts: Impacts on U(IV) speciation and stability over time. Environ. Sci. Technol. 2018, 52, 4601-4609. [CrossRef]

153. Etique, M.; Zegeye, A.; Gregoire, B.; Carteret, C.; Ruby, C. Nitrate reduction by mixed iron(II-III) hydroxycarbonate green rust in the presence of phosphate anions: The key parameters influencing the ammonium selectivity. Water Res. 2014, 62, 29-39. [CrossRef] [PubMed]

(C) 2019 by the authors. Licensee MDPI, Basel, Switzerland. This article is an open access article distributed under the terms and conditions of the Creative Commons Attribution (CC BY) license (http://creativecommons.org/licenses/by/4.0/). 